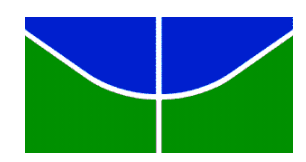

\author{
Universidade de Brasília - UnB \\ Instituto de Ciências Humanas - IH \\ Departamento de Serviço Social - SER \\ Trabalho de Conclusão de Curso \\ Orientadora: Prof ${ }^{\mathrm{a}}$ Dr $^{\mathrm{a}}$ Rosa Helena Stein \\ Discente: Thaís Caroline Sena de Oliveira
}

\title{
REDUZIDOS ÍNDICES DE EVASÃO E REINCIDÊNCIA CRIMINAL NO DISTRITO FEDERAL: O PAPEL DO SERVIÇO SOCIAL DA SEÇÃO PSICOSSOCIAL DA VARA DE EXECUÇÕES PENAIS SEGUNDO OS USUÁRIOS E AS ASSISTENTES SOCIAIS
}




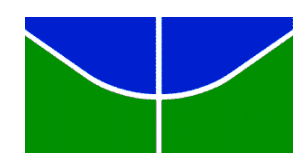

\author{
Universidade de Brasília - UnB \\ Instituto de Ciências Humanas - IH \\ Departamento de Serviço Social - SER \\ Trabalho de Conclusão de Curso \\ Orientadora: $\operatorname{Prof}^{\mathrm{a}} \operatorname{Dr}^{\mathrm{a}}$ Rosa Helena Stein \\ Discente: Thaís Caroline Sena de Oliveira
}

\title{
REDUZIDOS ÍNDICES DE EVASÃO E REINCIDÊNCIA CRIMINAL NO DISTRITO FEDERAL: O PAPEL DO SERVIÇO SOCIAL DA SEÇÃO PSICOSSOCIAL DA VARA DE EXECUÇÕES PENAIS SEGUNDO OS USUÁRIOS E AS ASSISTENTES SOCIAIS
}

Trabalho de Conclusão de Curso apresentada ao Departamento de Serviço Social - SER, da Universidade de Brasília - UnB, como requisito para a obtenção do grau de Assistente Social.

Brasília - Julho de 2009. 
Oliveira, T. C. S..

Reduzidos Índices De Evasão E Reincidência Criminal No Distrito Federal: O Papel Do Serviço Social Da Seção Psicossocial Da Vara De Execuções Penais Segundo Os Usuários E As Assistentes Sociais / Thaís Caroline Sena de Oliveira. - Brasília, 2009.

Trabalho de Conclusão de Curso - Universidade de Brasília, Departamento de Serviço Social, 2009.

Orientadora: Dr ${ }^{\mathrm{a}}$. Rosa Helena Stein. 


\title{
REDUZIDOS ÍNDICES DE EVASÃO E REINCIDÊNCIA CRIMINAL NO DISTRITO FEDERAL: O PAPEL DO SERVIÇO SOCIAL DA SEÇÃO PSICOSSOCIAL DA VARA DE EXECUÇÕES PENAIS SEGUNDO OS USUÁRIOS E AS ASSISTENTES SOCIAIS
}

\author{
Trabalho de Conclusão de Curso apresentada \\ ao Departamento de Serviço Social SER, da \\ Universidade de Brasília - UnB, como requisito \\ para a obtenção do grau de Assistente Social.
}

\section{Banca Examinadora:}

Professora orientadora: Dr $^{\mathrm{a}}$ Rosa Helena Stein

Professora: Daniela Neves de Sousa

Joselito da Silva Pacheco

Brasília, 15 de julho de 2009. 


\section{DEDICATÓRIA}

Dedico esta monografia a minha família, pela dedicação e compreensão ao longo desta jornada acadêmica.

Dedico também a todos os meus amigos que souberem ser gentis e companheiros, sempre com palavras de incentivo e apoio. Com carinho especial, dedico a todas às flores da turma de Serviço Social do primeiro semestre de 2006. 


\section{AGRADECIMENTOS}

À Professora e amiga Rosa Helena Stein por ter me guiado durante toda a execução do curso de Serviço Social com momentos de aprendizagem, inspiração e confraternização.

Aos gentis membros da banca examinadora, Professora Daniela Neves de Sousa e Sr. Joselito da Silva Pacheco, pela rica contribuição a este estudo.

Às amáveis profissionais da Seção Psicossocial da Vara de Execuções Penais, em especial as quatro Assistentes Sociais que atenciosamente se dispuseram a participar desta pesquisa, contribuindo imensamente com suas impressões.

Especialmente, agradeço aos usuários da SEVEP pela disposição de serem entrevistados e poderem compartilhar um pouquinho de suas histórias.

A todos que direta ou indiretamente contribuíram para que todo este esforço pudesse se tornar concreto, o meu muito obrigada! 


\section{RESUMO}

O Serviço Social no espaço sócio-jurídico data da gênese da própria profissão. A atuação de Assistentes Sociais junto a sentenciados e familiares no âmbito do Poder Judiciário do Distrito Federal iniciou-se em 1987 com a edição da Portaria interna no 03 que criou a Seção Psicossocial da Vara de Execuções Criminais - SEVEC. Com o objetivo de preparar o apenado para o retorno ao convívio social, uma equipe composta por Assistentes Sociais, Pedagoga, Psicólogas é requisitada a subsidiar a decisão de magistrados por meio da elaboração de relatórios sociais. A partir disso, como forma de identificar as percepções consolidada dos atores componentes desses serviços, esta pesquisa buscou analisar de que maneira assistentes sociais e usuários compreendiam a intervenção profissional do Serviço Social para os reduzidos índices de reincidência e fuga no Distrito Federal. Nessa perspectiva, inicialmente, foram analisados 90 relatórios do triênio 2006-2008 com vistas a traçar um perfil dos usuários; posteriormente, foram realizadas quatro entrevistas com Assistentes Sociais e quatro entrevistas com familiares de sentenciados atendidos na Seção com o objetivo de permitir a livre expressão acerca da temática.

PALAVRAS-CHAVE: Índice de evasão; índice de reincidência criminal; Serviço Social no campo sócio-jurídico; percepções dos usuários; percepções das Assistentes Sociais. 


\begin{abstract}
The Social Work practice in the Social-judicial field dates of genesis of the profession itself. The work of Social Workers with sentenced people and their families started in 1987 with the edition of Ordinance $n^{\circ} 03$ that created the Psicossocial of Court of Criminal Execution. In order to prepare the prisoner to return to the society, a staff made by Social Workers, Psychologists and Pedagogues was ordered to subsidize judicial decisions. From that point and observing the necessity of identification the perceptions of users and social workers about their comprehension of professional intervention of Social Work to the reduced score of reconviction and tax evasion in Distrito Federal. About methodology, it is been analyzed 90 reports signed by social workers in 2006, 2007 and 2008 with the objective to specify a prisoner profile; then, four interviews with social workers and four interviews with users attended in the Section was processed in order to allow the free expression of the participants about the thematic.
\end{abstract}

KEY-WORDS: Tax evasion; score of reconviction; Social Work practice in the Socialjudicial field; perception of users; perception of social workers. 


\section{LISTA DE SIGLAS}

CAJE - Centro de Atendimento Juvenil Especializado

CAPS - Centro de Apoio Psicossocial

CFESS - Conselho Federal de Serviço Social

CIR - Centro de Internação e Reeducação

CP - Código Penal Brasileiro

CPI - Comissão Parlamentar de Inquérito

CPP - Centro de Progressão Penitenciária

CRESS - Conselho Regional de Serviço Social

DEPEN - Departamento Penitenciário Nacional

EAPE - Equipe de Estudos e Acompanhamento de Presos e Egressos

ECA - Estatuto da Criança e Adolescente

FHC - Fernando Henrique Cardoso

FUNAP - Fundação de Amparo ao Trabalhador Preso

GDF - Governo do Distrito Federal

IBGE - Instituto Brasileiro de Geografia e Estatística

IML - Instituto Médico Legal

INFOPEN - Sistema de Informações Penitenciárias

IPEA - Instituto de Pesquisa Econômica e Aplicada

LEP - Lei de Execuções Penais

LOAS - Lei Orgânica de Assistência Social

MPDFT - Ministério Público do Distrito Federal e Territórios

PDRE/MARE - Plano Diretor da Reforma do Estado

PEA - População Economicamente Ativa

PTR - Programa de Transferência de Renda

SESIPE - Subsecretaria de Sistema Penitenciário

SEVEP - Seção Psicossocial da Vara de Execuções Penais

STF - Superior Tribunal Federal

STJ - Superior Tribunal de Justiça

TCLE - Termo de Consentimento Livre e Esclarecido

TJDFT - Tribunal de Justiça do Distrito Federal e Territórios

UnB - Universidade de Brasília

VEP - Vara de Execuções Penais

VEPEMA - Vara de Execuções de Penas e Medidas Alternativas 


\section{SUMÁRIO}

\begin{tabular}{|c|c|}
\hline ÇÃO.......... & 01 \\
\hline 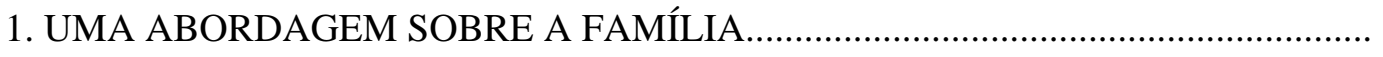 & 07 \\
\hline 1.1 Informalidade e Desemprego Estrutural: A Nova Configuração do Trabalho............. & 09 \\
\hline 1.2 Políticas Sociais Brasileiras E A Sua Configuração Neoliberal................................... & 13 \\
\hline 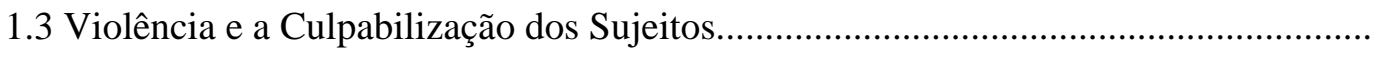 & 15 \\
\hline 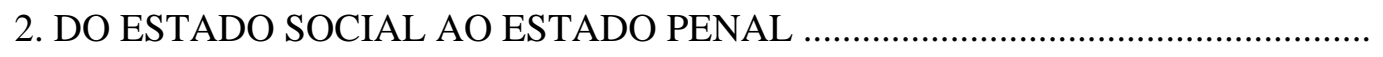 & 19 \\
\hline 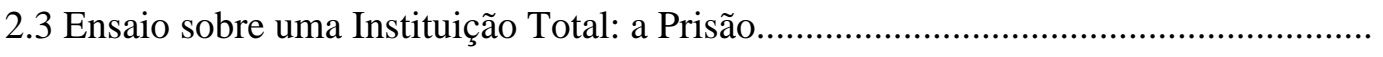 & 23 \\
\hline 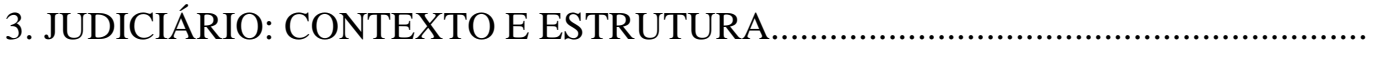 & 28 \\
\hline 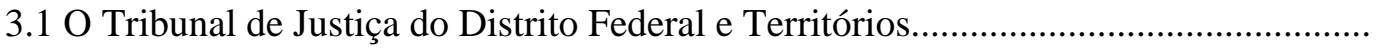 & 31 \\
\hline 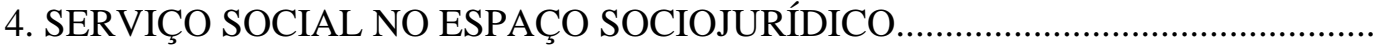 & 33 \\
\hline 4.1 Processos de Trabalho na Seção Psicossocial da Vara de Execuções Penais................ & 37 \\
\hline $\begin{array}{l}\text { 5. UM OLHAR MAIS PROFUNDO SOBRE O OBJETO DE PESQUISA: A } \\
\text { REINCIDÊNCIA CRIMINAL E A EVASÃO. }\end{array}$ & 43 \\
\hline ANÁLISE DE DADOS & 51 \\
\hline 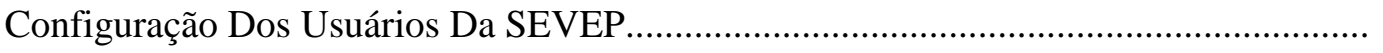 & 51 \\
\hline 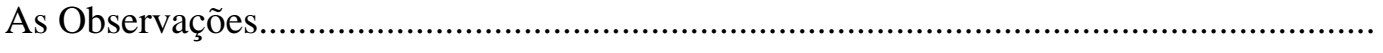 & 58 \\
\hline As Entrevistas..1.1. & 63 \\
\hline 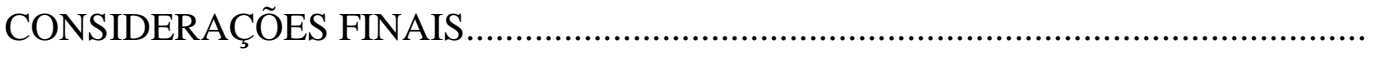 & 73 \\
\hline 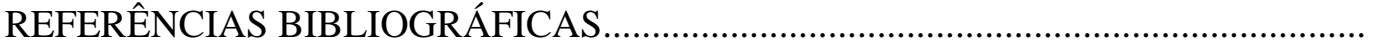 & 75 \\
\hline ...... & 80 \\
\hline
\end{tabular}




\section{INTRODUÇÃO}

O Judiciário é historicamente uma instituição ligada ao controle social promovido pelo Estado, inserido no modo de produção capitalista como aparato legal para legitimação deste: "na sociedade capitalista, o reino da mercadoria desdobra-se no circuito das relações contratuais, exigindo um conjunto de códigos que formalizam e institucionalizam as relações de propriedade", grifos da autora (IAMAMOTO, 2004:278). Desta forma, Souza (2004) ressalta a função social do poder judiciário, qual seja a prestação de serviços jurisdicionais e interpretação na aplicabilidade da lei, objetivando a resolução de conflitos e dissídios entre os cidadãos, entre os cidadãos e o Estado e no seu interior - do ponto de vista crítico, é preciso compreender essa (des)função social a partir da própria interpretação do direito positivista alienado à vida real, ao histórico-estrutural. Segundo essa análise, Iamamoto (2004) citando Fávero identifica a contradição de dois papéis desempenhados pelo Poder Judiciário: o primeiro de natureza punitiva, essencialmente dirigido aos setores marginalizados da sociedade; e o segundo de natureza distributiva, que implica na vontade política da adoção de critérios compensatórios e protetores para esses setores, tais como a instituição de padrões mínimos de eqüidade, integração e coesão social. Alia-se a esse entendimento a inserção do Serviço Social que inicialmente adotou o conservadorismo do direito em suas intervenções.

A atuação do Serviço Social junto ao Poder Judiciário confunde-se com a própria gênese da profissão. As primeiras intervenções da categoria em Fóruns, comarcas e corregedorias foram observadas nos estados de Rio de Janeiro, São Paulo, Espírito Santo, Minas Gerais, Rio Grande do Sul, Paraná, Pernambuco, Goiás e Distrito Federal no final da década de 1930. Os assistentes sociais foram requisitados para subsidiar as decisões judiciais junto às Varas de Família, de Órfãos e Sucessões, de Execuções Criminais e dos Juizados Especiais Cíveis e Criminais. Segundo Souza (ibidem), a inserção do Serviço Social no Poder Judiciário sucedeu-se, por um lado, devido a complexificação das relações sociais impostas pelo capital, ao próprio poder, e, por outro, em virtude do movimento da profissão em busca de seu reconhecimento por meio da renovação de práticas e do aspecto criativo de novas estratégias. De acordo com o autor, o Serviço Social foi, provavelmente, a primeira profissão de conhecimento 
não-jurídico ou para-jurídicas a ser inserida nos tribunais tanto brasileiros quanto internacionais. (SOUZA, 2004).

O início da atuação dos Assistentes Sociais no Poder Judiciário do Distrito Federal é caracterizado por dois aspectos: o primeiro de cunho histórico-processual coincide com o movimento de redemocratização do país que teve como marco a Constituição de 1988 na qual a justiça social é referendada por meio da aplicação dos direitos sociais. Nessa perspectiva cabe ao judiciário a garantia desses direitos não somente aos cidadãos de modo genérico, mas para os seus próprios servidores que concebidos como sujeito de direitos, demandam deste poder todo um aparato jurídicolegal que viabilizem a sua efetivação. O segundo movimento, considerando a conjuntura política, é o de reflexão crítica no interior da própria profissão iniciada em meados da década de 1960 em toda América Latina. Tal movimento é intensificado nacionalmente a partir do fim da década de 1970, quando há uma desmistificação do messianismo gestado na categoria, em prol de um novo paradigma que pregava a atuação profissional com base na ação revolucionária ligada aos movimentos sociais e que negava o espaço institucional como campo de intervenção, caracterizando-o como mero reprodutor da ordem capitalista vigente (SOUZA, 2004).

Para Iamamoto (2004) o trabalho do Serviço Social é compreendido a partir de seu objeto de intervenção, qual sejam as expressões fenomênicas da questão social. Com base na compreensão do modo de produção capitalista, da sua relação primer entre capital-trabalho, ou seja, a expropriação dos meios de produção da coletividade e a apropriação privada da atividade ontológica do ser social, o trabalho, é que se faz possível a sinalização de algumas expressões da questão social manifestas que se encontram à margem dessa relação dialética, são elas: as desigualdades econômicas, políticas e culturais de classe. Ainda nessa perspectiva, todo o aparato ideológico hegemônico de naturalização da pobreza e da violência social, desconstruindo qualquer análise histórica, traz consigo a perversa criminalização da questão social, encarada como “caso de polícia”. A autora entende, então, que a atuação do assistente social nesse campo tem como desafio o desvelamento do modo de vida, cultura, padrões de sociabilidade, necessidades desses sujeitos que demandam os serviços jurídicos como última instância de resolução dos conflitos "uma vez que a busca pela proteção judicial tem lugar quando todos os demais recursos são exauridos” (IAMAMOTO, 2004: 283). 
Retomando a análise de Souza das condições sócio-históricas da atuação do Serviço Social no Distrito Federal, o autor faz uma distinção entre os assistentes sociais que atuam nas áreas ditas meio, que são atividades técnico-adiministrativas caracterizadas pela execução de benefícios e programas assistenciais voltados para o bem-estar dos servidores; e nas áreas-fim, apoio técnico-judiciário caracterizado pelo trabalho em setores psicossociais. No primeiro caso, a inserção profissional se dá junto a Seções de Assistência ou Serviço Social, caracterizadas pela subordinação a seções nas áreas de saúde, recursos humanos ou de benefícios assistenciais. A demanda por esses serviços poder ser considerada interna na medida em que somente servidores, magistrados e dependentes têm acesso. $\mathrm{O}$ autor avalia que esse tipo de atuação vinculase a um baixo nível hierárquico na medida em que poucos são os assistentes sociais que alçam cargos de chefia ou, mesmo, estão subordinados a outras seções chefiadas por médicos, administradores e psicólogos. Nos setores psicossociais, a inserção profissional está pautada na natureza de conflitos e dissídios que chegam ao Tribunal por intermédio das varas e juizados. Seus usuários, diferentemente das áreas-meio, são sujeitos externo-institucional, como adolescentes em conflito com a Lei, adultos que cometeram crimes, adultos com transtornos psiquiátricos que cometeram um crime, entre outros (SOUZA, 2004).

Nessa perspectiva, entre as possíveis inserções em setores psicossociais, a atuação do Serviço Social na Seção Psicossocial da Vara de Execuções Penais - SEVEP visa o atendimento a demandas externas ao Tribunal advindas de conflitos e dissídios encaminhados a Vara de Execuções Penais em que se impõe uma pena privativa a liberdade, livramento condicional ${ }^{1}$ ou medida de segurança ${ }^{2}$. No Projeto de Intervenção

1 Art. 83 do Código Penal Brasileiro (1984) prevê que o livramento condicional será concedido condenado a pena privativa de liberdade igual ou superior a 2 (dois) anos, desde que:

I - cumprida mais de um terço da pena, não sendo reincidente em crime doloso e tendo bons antecedentes;

II - cumprida mais da metade se o condenado for reincidente em crime doloso;

III - comprovado comportamento satisfatório durante a execução da pena, bom desempenho no trabalho que lhe foi atribuído e aptidão para prover à própria subsistência;

IV - tenha reparado, salvo efetiva impossibilidade de fazê-lo, o dano causado pela infração;

$\mathrm{V}$ - cumprido mais de dois terços da pena, nos casos de condenação por crime hediondo, prática da tortura, tráfico ilícito de entorpecentes e drogas afins, e terrorismo, se o apenado não for reincidente específico em crimes dessa natureza.

2 A medida de segurança é atribuída ao agente considerado inimputável - aquele que por anomalia psíquica ou retardo mental não pode responder por si judicialmente. O juiz determinará sua internação ou 
da então equipe de Estudos e Acompanhamento de Presos e Egressos - EAPE (hoje denominada como Equipe de Acompanhamento às Penas Restritivas de Liberdade), afirma-se que o objetivo da intervenção é "minimizar a perda de benefícios concedidos, por meio de estratégias de acompanhamento aos sentenciados e egressos do Sistema Penitenciário do Distrito Federal, evitando, assim, a reincidência penal". Tendo em vista que para além da redução da reincidência penal, a diminuição dos índices de foragidos também pode ser considerado outro aspecto desse objetivo - visto que sendo as Saídas Especiais $^{3}$ um benefício concedido, em que seus dados sobre foragidos são fontes importantes para implementação de novas políticas públicas - este estudo propôs-se a analisar em que medida a atuação do Assistente Social contribui para os reduzidos índices de foragidos e índices de reincidência no Distrito Federal.

Uma primeira justificativa para a execução deste estudo é que, apesar da intervenção do Serviço Social no espaço sócio-jurídico ${ }^{4}$ ser uma das suas primeiras formas de atuação da profissão, é consensual que, diferentemente de outras produções a cerca das práticas profissionais tidas como clássicas à profissão - especificamente as relacionadas às políticas sociais -, estudos sobre a temática sociojurídica são muito reduzidos, ou mesmo a sua publicização por meio de livros, revistas e artigos ainda é incipiente.

A problematização do debate sobre essa área de atuação ainda restringe-se ao Serviço Social nas Varas de Família - inicial campo para assistentes sociais no Poder

seu tratamento ambulatorial, quando o fato previsto como crime for punível com detenção. A internação, ou tratamento ambulatorial, será por tempo indeterminado, perdurando enquanto não for averiguada, mediante perícia médica, a cessação de periculosidade. O prazo mínimo deverá ser de 1 (um) a 3 (três) anos (CÓDIGO PENAL, 1940).

${ }^{3}$ Saída Especial é um benefício concedido aos internos que preencham os requisitos elencados no artigo 123 da Lei de Execução Penal, quais sejam: comportamento adequado; cumprimento mínimo de 1/6 da pena, se o condenado for primário, e 1/4, se reincidente; e compatibilidade do benefício com os objetivos da pena, além de outros que possam vir a ser determinados. No Distrito Federal, a execução penal conta com seis saídas especiais para feriado: Páscoa, Dia das Mães, Dia dos Pais, Dia das Crianças, Natal e Ano Novo.

${ }^{4}$ Segundo Iamamoto (2004), por sócio-jurídico entende-se as atuações da profissão junto às instituições do Poder Judiciário strito sensu - Tribunais de Justiça e suas instâncias - e junto a instituições que realizam medidas emanadas desse poder, como as medidas protetivas ou sócio-educativas, em presídios e ainda Conselhos de Direito e Conselhos Tutelares. 
Judiciário - visto que as novas perspectivas sobre família, pós-expansão dos direitos sociais, advento de um processo de luta pela redemocratização nacional e queda da ditadura além do processo de crítica do Serviço Social latino-americano, prescindiram de tal instrumentalização para a profissão. O novo ordenamento sóciojurídico expresso pela Constituição de 1988, bem como por outros mecanismos legais como o Estatuto da Criança do Adolescente e a Lei Orgânica da Assistência Social legitimaram o exercício do poder por novos atores sociais, o que Bruno apud Valente (2006) analisa como a horizonatalização em detrimento da hierarquização das relações sociais, estando assim mais pessoas aptas a litigiar. O Poder Judiciário como resposta a essa conjuntura demanda a atuação do Serviço Social na realização de estudo social para entendimento da complexidade dessa família contemporânea.

Para além das poucas pesquisas nessa tradição judiciária da execução penal, o impacto dessa inserção profissional ainda não é objeto desses parcos estudos. Contempla-se as mediações desse trabalho, seus processos e a relação entre teoriaprática, porém desvincula-se a contribuição efetiva para os usuários a curto e a longo prazo. Consensualmente, tem-se o reconhecimento sobre a importância da intervenção do Serviço Social no que diz respeito aos aspectos de subsídios às decisões judiciais e também como mecanismo de suporte à institucionalização dos dissídios. Entretanto, é preciso identificar como o usuário dos serviços compreende a atuação do assistente social, de que forma ele a percebe e reconhece a contribuição para o seu desenvolvimento como sujeito de direitos.

Para abarcar o tema, esse estudo está dividido em cinco capítulos, assim estabelecidos: o primeiro tratará sobre a questão da família contemporânea a partir da perspectivas das alterações que a ordem neoliberal impõe a esse ator; o segundo capítulo diz respeito a passagem de um Estado Social para um Estado Penal; o terceiro capítulo visa abarcar o espaço institucional onde se procede este estudo por meio da compreensão, primeiramente, do Poder Judiciário a que o Tribunal de Justiça do Distrito Federal está submetido; o trabalho do Serviço Social na Seção Psicossocial da Vara de Execuções Penais do Tribunal de Justiça do Distrito Federal e Território é o foco do quarto capítulo; e o quinto e último capítulo se propõe a analisar o objeto de pesquisa, qual seja a reincidência criminal e a evasão penitenciária. Em seguida, são 
apresentados os dados coletados na Seção Psicossocial da Vara de Execuções Penais do Distrito Federal e as considerações finais a que esse estudo chegou.

Metodologicamente, esta pesquisa se caracteriza pela análise quanti-qualitativa dos dados e tem por base o método materialista histórico-dialético. Segundo Pires (1997), esse método é apresentado pelo movimento do pensamento através da materialidade histórica da sociedade, em outras palavras, significa descobrir as bases que definem a forma organizativa dos homens em sociedade através da história. $\mathrm{Na}$ produção de conhecimento científico, o método materialista histórico-dialético pressupõe a superação da dicotomia sujeito e objeto para que se possa compreender a totalidade da realidade.

Nessa perspectiva de compreensão da totalidade e complexidade do problema, a presente pesquisa se utilizará de quatro técnicas utilizadas seqüencialmente, a saber: análise documental; observação não-participante ou simples; entrevista semiestruturada; e entrevista de grupo focal, ou simplesmente grupo focal. Não necessariamente, a ordem das técnicas seguirá a enunciação acima, visto que a análise documental será utilizada em dois momentos distintos que se interpolarão ao início da coleta de dados e ao fim.

Enfocando mais nas técnicas de pesquisas, foram implementadas sete entrevistas distribuídas da seguinte forma: quatro com as Assistentes Sociais da SEVEP, duas com familiares de sentenciado, uma entrevista de grupo focal. Todas as entrevistas foram precedidas de um momento de observação dos atendimentos realizados pelas Profissionais. Como forma de se analisar a configuração dos usuários da Seção Psicossocial também foi realizado um levantamento com 90 relatórios dos últimos três anos de atividade. 


\section{UMA ABORDAGEM SOBRE A FAMÍLIA}

Pensar a atuação do Serviço Social no âmbito das instituições judiciárias é tratar do seu objeto - as expressões dos fenômenos da questão social - para além da abordagem funcionalista: profissional e clientela. Não somente nas Varas que atuam especificamente no trato da família - Vara da Infância e Juventude, Órfãos e Sucessões e de Famílias - mas nas Varas Criminais ou Penais, a intervenção junto à família, contempla um eixo mais amplo da sociabilidade dos sentenciados, resgatando, assim, a história de vida desse sujeito coletivo que expressa, em seu particular, facetas da realidade social do modo de produção capitalista no seu espectro mais contemporâneo, a reestruturação capitalista.

O neoliberalismo, que ideologicamente dá arcabouço a essas mudanças estruturais do capitalismo, configura-se como uma política de ajustes estruturais, inserida num contexto de ajustes econômico mundiais, fomentada no Consenso de Washington. Incorporada pelos governos brasileiros a partir da década de 1990, com especial destaque para os governos de Collor, FHC e o atual governo Lula, as políticas neoliberais promovem a precarização das condições de trabalho - destacando-se aí, o desemprego, o subemprego, a informalidade, e outras expressões que exemplificam o contexto de desregulamentação dos contratos de trabalho com garantias mínimas de sustentabilidade do trabalhador.

Uma segunda expressão desse modelo configura-se na redução a patamares mínimos de intervenção do Estado no campo socioeconômico, incutindo na família a autogestão de suas necessidades. De acordo com Mattoso citado por Fávero (2007), esses ajustes atingiram as políticas sociais triplamente, a saber:

Primeiro, pela redução de recursos que acompanhou os diversos ajustes fiscais e deteriorou qualitativa e quantitativamente os serviços sociais básicos, sobretudo nas áreas com elevada participação de recursos da esfera federal, como a saúde. Segundo, pela redução do uso de políticas universalistas e pela generalização do uso de programas sociais extremamente focalizados, sem estratégia, assistencialistas e clientelistas na relação com o público-alvo. Terceiro, porque estas mudanças vieram, quase sempre, acompanhadas de propostas de reformas sociais explicitamente privatizantes, favorecidas pela falência organizada dos serviços públicos (MATTOSO apud FÁVERO, 2007:07). 
Em conseqüência desses mecanismos neoliberais, a situação de pobreza vivenciada por grande parcela da população tem-se agravado. São milhares de pessoas que para além da redução de suas rendas, se vêem desamparados pelo Estado que os nega o acesso básico a seus direitos - Telles interpreta como "condição de privação de direitos" (1992, p. 352). Fávero (2007) apresenta que as condições de pobreza podem ser entendidas como um conjunto de ausências de renda, educação, trabalho, moradia e rede familiar e social de apoio. Concatenando com uma das definições de Lavinas (2002), pode-se dizer que pobreza é um estado de carência, privação, de não satisfação de necessidades básicas que pode colocar em risco a própria condição humana.

Uma segunda expressão que designa esses sujeitos é a exclusão social, outro termo também bastante discutido na literatura. Para Paugam (1999), um dos idealizadores da denominação "novas formas da pobreza", exclusão social não se resume à carência de bens materiais, mas também remete a idéia de status social inferior e desvalorizado. Segundo Lavinas (2002), exclusão implica considerar aspectos subjetivos, que mobilizam sentimentos de rejeição, perda de identidade, falência dos laços comunitários e sociais, resultando numa retração das redes de sociabilidade, com quebra de solidariedade e reciprocidade. Uma terceira interpretação está na visão de Castel (2003) que prefere a utilização do termo marginalização para caracterizar os desafiliados sociais: indivíduos que anteriormente à crise da sociedade salarial estavam integrados, de forma subordinada e dependente, e que agora são populações "à margem" (Idem, p.29).

Para além da conotação estruturante da sociedade capitalista, é importante abordar as mudanças nos padrões familiares contemporâneos. Fávero (2007), se utilizando dos estudos de Eric Hobsbawn (1997), faz uma retomada do processo que culminou com a revolução cultural, que segundo o historiador pode ser traduzida na "transformação das convenções de comportamento social e pessoal". Uma das principais peças dessa revolução são as conquistas femininas do século passado, em especial o direito de ingressar no mercado de trabalho.

O modelo de família nuclear burguesa monogâmica composta de pai, mãe e filhos, em que o primeiro era responsável pela manutenção da casa inserido no mundo do trabalho (produção capitalista); e o segundo ator era responsável pelo trato dos filhos 
e da casa (reprodução capitalista), vem sendo alterado progressivamente com a mudança da relação de gêneros, o direito ao divórcio, o nascimento de ilegítimos, aumento de famílias monoparentais (em especial as chefiadas por mulheres) e das uniões consensuais. É preciso compreender, porém, que essas mudanças, por vezes, ainda são analisadas dentro dos padrões de anormalidade, desordem e disfuncionalidade em comparação com o modelo tradicional (FÁVERO, 2007).

A precariedade das condições de vida contribui cada vez mais para que esses novos arranjos familiares sejam implementados. A luta pela sobrevivência dificulta a conciliação da vida íntima e a adoção de relações conjugais tendo a criança como centro. Dessa forma o modelo familiar nuclear não pode sobrepor-se a realidade histórica para se avaliar as "carências, desvios ou anormalidades", com o objetivo de se enquadrar, por meio de procedimentos profissionais ou imposições legais, àquele modelo burguês ou a punição ou interdição para os que não se enquadrarem (Idem).

Em síntese, a caracterização dos usuários dos serviços sociais nas instituições sócio-jurídicas passa por uma interpretação dialética das singularidades em relação a totalidade. O Serviço Social a partir de sua abordagem marxista deve compreender o caso que lhe é repassado a partir das mediações que este apresenta das relações sociais do modelo societário capitalista. A culpabilização das famílias pelos "crimes" que algum de seus sujeitos tenha cometido pode ser interpretada como uma reação burguesa em vista das crises cíclicas do próprio capitalismo.

\subsection{Informalidade E Desemprego Estrutural:}

\section{A Nova Configuração Do Trabalho}

A partir de meados da década de 1970, nos países desenvolvidos, e em fins dos anos 1980, nos país latinoamericanos, observa-se um quadro inflacionário e recessivo que comprometia a garantia dos lucros das empresas capitalistas, bem como o acirramento das lutas trabalhistas do fim da década de 1960 que reivindicavam a participação nos ganhos econômicos através de um sindicalismo de base ainda fortemente marcado pelo "fantasma" do socialismo do leste europeu. Esses dois 
movimentos vão colocar em xeque a hegemonia do capitalismo como projeto societário (ANTUNES e POCHMANN, 2007).

Como forma de superação desse quadro crítico e retomada da reprodução social, implementa-se, nos termos de Davi Harvey (1992), a alternativa de flexibilização da acumulação capitalista que visa a redução dos custos dos fatores de produção através da eliminação de barreiras para sua expansão. A transnacionalização do capital e a sua concentração (monopolização) em busca de economias mais rentáveis vão se configurar numa espécie de predatismo sócio-econômico: enquanto nos mercados centrais europeus e norte-americano vive-se a crise da empregabilidade, visto o alto custo da mão-de-obra; nos mercados periféricos, a situação é de extrema precariedade das relações trabalhistas, tenta-se ao máximo reduzir os curtos desse fator de produção.

A acumulação flexível se inscreve no âmbito ideológico neoliberal em oposição à lógica social-democrata do Estado de Bem Estar Social. Em termos gerais, essa doutrina possui duas conotações: a primeira de retorno ao liberalismo clássico que propunha a regulação da economia através da "mão invisível" de Adam Smith, que transplantado para esse último quartel do século $\mathrm{XX}$ vai representar a desregulamentação do Estado no trato da economia. O segundo movimento da ótica neoliberal é representado, lembrando a tese de François Chesnais (1996), na mundialização do capital por meio do aumento de sua financeirização em contraposição ao seu caráter produtivo.

Outro mecanismo da flexibilização do capital é a chamada reestruturação produtiva que, por meio dos pilares de inovações organizacionais, inovações tecnológicas e inovações sócio-metabólicas (ALVES, 2007), propõe-se ao desenvolvimento de uma nova forma de extração da mais-valia baseado não mais nos moldes fordista-taylorista, mas num modelo de investimento na administração eficiente, de aperfeiçoamento do maquinário e de desregulamentação da força de trabalho.

As novas formas de inserção no mercado de trabalho se mostram cada vez mais eficientes nos três termos em que vêm se estruturando: flexibilização, precarização e terceirização. Cada forma na sua peculiaridade, todas concorrem para a desregulamentação dos direitos trabalhistas conquistados até então, de forma a produzir um contingente enorme de trabalhadores desprotegidos socialmente. Constata-se, 
portanto, a escassez dos postos de trabalho formais que conjuntamente ao crescimento das taxas de desemprego formam o quadro deplorável do atual mercado de trabalho.

De acordo com números da Pesquisa Mensal de Emprego realizada pelo Instituto Brasileiro de Geografia e Estatística - IBGE, o Brasil conta hoje com uma População Economicamente Ativa - PEA na ordem dos 23 milhões, sendo que destes 8,8\% estão desempregados de forma aberta (dados de maio de 2009). Essa taxa somente consta daqueles que estão incluídos na PEA, porém se inserirmos os grupos caracterizados como "marginalmente ligadas à $\mathrm{PEA}^{5 ",}$, "desalentados", "que saíram do último trabalho no período de 365 dias" e "subocupados por insuficiência horas trabalhadas"” veremos que esse número cresce para 23\%. Interessante observar que, apesar das taxas de desemprego aberto virem caindo mês a mês - tendência normal se comparada com anos anteriores - o efetivo de pessoas desocupadas vem crescendo: no início do ano eram 1.567 mil desempregados, já no mês de maio esse número cresceu para 2.036 mil.

No que tange o aspecto das relações trabalhistas, o Instituto de Pesquisa e Economia Aplicada - IPEA, por meio do seu boletim de conjuntura de 2007, divulgou a evolução da ocupação por vínculo de empregatício dos brasileiros demonstrando que os trabalhadores intitulados por "conta própria" no acumulado de 2006 a julho de 2007 tiveram um incremento de $5,2 \%$ de sua população. Vale lembrar que no período analisado, os trabalhadores com carteira assinada tiveram uma evolução de 4,4\%. O IBGE aponta, ainda, que, evolutivamente, os caracterizados como "conta própria", "empregados sem carteira assinada no setor privado" e "empregados sem carteira assinada no setor publico" tem aumentado ao longo dos últimos anos: no ano de 2008, estes representavam 7.782 mil pessoas.

\footnotetext{
5 "São definidas como marginalmente ligadas à população economicamente ativa na semana de referência as pessoas não-economicamente ativas na semana de referência que trabalharam ou procuraram trabalho no período de referência de 365 dias e estavam disponíveis para assumir um trabalho na semana de referência" (IBGE, 2007:21).

6 “São definidas como desalentadas as pessoas marginalmente ligadas à população economicamente ativa na semana de referência da pesquisa que procuraram trabalho ininterruptamente durante pelo menos seis meses, contados até a data da última providência tomada para conseguir trabalho no período de referência de 365 dias, tendo desistido por não encontrar qualquer tipo de trabalho, trabalho com remuneração adequada ou trabalho de acordo com as suas qualificações" (IBGE, 2007:21).

7 "Define-se como subocupadas por insuficiência de horas trabalhadas as pessoas que trabalharam efetivamente menos de 40 horas na semana de referência, no seu único trabalho ou no conjunto de todos os seus trabalhos, gostariam de trabalhar mais horas que as efetivamente trabalhadas na semana de referência e estavam disponíveis para trabalhar mais horas no período de 30 dias, contados a partir do primeiro dia da semana de referência" (IBGE, 2007:24).
} 
O declínio da empregabilidade se inscreve na substituição do trabalho vivo (do operário) pelo trabalho morto (do maquinário). A chamada lean production ou liofização organizacional trata do "enxugamento" das empresas do operário assalariado e pela ampliação do maquinário tecno-científico. Mistifica-se o papel do proletário que passa a ser chamado de colaborador numa significativa menção ao corporativismo burguês (ANTUNES e POCHMANN, 2007).

A quase eliminação do trabalhador vivo do processo produtivo chama àquele que ainda persiste "vivo" a uma polivalência de sua atuação. O trabalhador multifuncional, desespecializado deve intervir de forma a complementar a parte pensante daquela máquina substitutiva de trabalhadores. Para tal, faz-se necessário o maior número de horas em condições de maior stress físico e psicológico.

A informatização do trabalho é outra característica da reestruturação produtiva. A permuta do trabalho material, ou seja, aquele que efetivamente produz valor de uso, pelo trabalho imaterial ${ }^{8}$, aquele que produz valor de troca, transplanta a lógica do necessário para a lógica fetichista. Vive-se, pois, a "sociedade do conhecimento" baseada na esfera da comunicação e do marketing. Segundo Antunes e Pochmann

Estamos presenciando a sociedade do logos, da marca, do simbólico. Nela, o design da Nike, a concepção de um novo software da Microsoft, o modelo novo da Benetton, resultam do labor chamado imaterial, que, articulado ao trabalho material, expressa vivamente as formas contemporâneas da criação do valor. São novas formas de trabalho e de criação do valor (Ibid. p. 199).

Todas essas formas precárias de inserção no trabalho vão representar a restrição dos direitos sociais como exigência do capital global a fim de uma sobre-extração da mais-valia. No item a seguir se perceberá que esse desmonte do trabalho tem influência na forma como o Estado vai lidar com esse quantitativo da população que, não inseridas no mercado de trabalho, demandam mais políticas sociais.

\footnotetext{
${ }^{8}$ Vale destacar que se reconhece a polêmica existente acerca das categorias "trabalho material" e "trabalho imaterial" dentro do meio acadêmico, porém como não se configura objetivo deste estudo reportar essa discussão, peço que façam essa observação na leitura deste capítulo e que compreendam que a utilização das mesmas categorias foi uma opção feita pelos autores referidos aqui.
} 


\subsection{Políticas Sociais Brasileiras E A Sua Configuração Neoliberal}

As políticas sociais brasileiras na contemporaneidade não fugiram do contexto estruturante sócio-econômico que marcou as últimas duas décadas. Em tempos neoliberais de recrudescimento da questão social e o retorno ao Estado mínimo, os direitos sociais foram os primeiros a serem solapados. Vive-se um processo de desfiliação social, como apresentado anteriormente por Castel (2003), ou de desassistencialização da população, segundo Pereira (1998), no que concerne o atendimento das garantias sociais. Como se verá a seguir, o Estado brasileiro passa por um momento de revisitação dos seus patamares legais instituídos através da Constituição de 1988 que serão implementados ora com vistas a redução de direitos, ora com vista a ampliação dos mesmos. A opção por um desses dois caminhos vai marcar a relação entre Estado, família e indivíduo nos últimos anos.

O marco legal da construção do Estado Democrático de direito brasileiro se dá por meio da Constituição da República Federativa do Brasil de 1988. A carta magna é definitivamente moldada nas bases da social-democracia, que, segundo Boschetti (2006), chega ao país com quase quarenta anos de atraso em uma conjuntura nada favorável a ampliação da ação do Estado. Emanada do povo ${ }^{9}$ por meio das lutas pela redemocratização após vinte anos de ditadura militar, a Constituição brasileira vigente é singular ao incluir a responsabilização do Estado em garantir os direitos sociais, quais sejam: a educação, a saúde, o trabalho, a moradia, o lazer, a segurança, a previdência social, a proteção à maternidade e à infância, a assistência aos desamparados ${ }^{10}$.

Outras legislações que se inserem na mesma ótica de ampliação de direitos são citadas por Mioto (2008), a saber: Lei $n^{\circ} 8.080$ de 1990 que dispõe sobre as condições de promoção, proteção e recuperação da saúde; Lei $n^{\circ}$ 8.042, que trata da participação da comunidade na gestão do Sistema Único de Saúde - SUS; Lei Orgânica da

\footnotetext{
${ }^{9}$ Parágrafo único do art. $1^{\text {o: }}$ "Todo o poder emana do povo, que o exerce por meio de representantes eleitos ou diretamente, nos termos desta Constituição" (BRASIL, 1988).

${ }^{10} \mathrm{O}$ capítulo II trata especificamente dos direitos sociais. A inscrição destes abre o capítulo no artigo $6^{\circ}$ da Constituição. Segundo a emenda $\mathrm{n}^{\circ} 26$ de 2000, a moradia também passa a ser considerada um direito social (BASIL, 1988).
} 
Assistência Social (LOAS) de 1993; Estatuto da Criança e do Adolescente - ECA de 1990; Estatuto do Idoso de 2003; entre outras regulamentações e normas operacionais.

Em contrapartida, muitas políticas públicas implementadas desde a década de 1990 vão na contramão do direito, haja visto os governos reacionários que se instauram no país, como Collor, que vetou a Lei Orgânica da Assistência Social na sua primeira tentativa de ser promulgada; Sarney, que instituiu planos econômicos de arrefecimento dos salários da população brasileira; e Fernando Henrique Cardoso que instaurou o Plano Diretor da Reforma do Estado (PDRE/MARE).

Outras formas de lapidação dos direitos mais atuais se inserem no âmbito dos Programas de Transferência de Renda (PTRs), vide o Bolsa Família, que objetivam o enfrentamento (em outros termos, controle) da pobreza. Contudo, como Stein (2008) afirma, ao invés de representarem a última possibilidade de acesso à renda, configuramse como a primeira e única possibilidade de acesso a qualquer recurso, já que com a transmutação do mundo do trabalho e conseqüentemente a redução da proteção social por meio do seguro, a assistência social mediada pelos PTRs vai requisitar de seus beneficiários o investimento em "capital humano". Além do mais, os assistidos são selecionados entre "os pobres entre os mais pobres", a focalização é a face mais cruel desses programas, os testes de meio para o cadastramento e as condicionalidades representam a outra face perversa dos PTRs visto que significam uma segunda tributação, um "repagamento" pelos seus direitos se observarmos que os recursos para esse programa são oriundos de tributos pagos por todos os brasileiros.

Os outros espaços desocupados pelo Estado vão ser preenchidos pelo chamado Terceiro Setor, que responsabiliza a sociedade civil no trato da questão social $^{11}$. O voluntariado, as organizações não-governamentais, chamadas de "entidades sociais" são as expressões dessa nova configuração protetiva que se instaura a partir de década de 1990. Propõe-se uma parceria entre o setor público e a sociedade civil, em que este último, entra com maior participação, um chamamento a soluções em âmbito comunitário no viés da solidariedade e caridade.

Mioto (2008), sobre essa contextualização brasileira, declara que

\footnotetext{
${ }^{11}$ Para maiores informações a cerca do tema, ver Revista Serviço Social \& Sociedade $\mathrm{n}^{\mathrm{o}} 73$ da Editora Cortez.
} 
A partir dos anos 1990 se acirra no Brasil um processo de disputa entre diferentes projetos políticos para a sociedade brasileira, nos quais a questão da proteção social joga papel principal. Nesse âmbito, o processo é caracterizado, por um lado, pela tensão entre a afirmação da proposta de institucionalização da proteção social nos moldes definidos pela Constituição de 1988 e a sua desconstrução através da retração do Estado. Esta inclui tanto as privatizações como a adesão ao princípio da focalização nas políticas públicas e a afirmação do pluralismo de bemestar. Por outro lado, pela tensão entre a afirmação da família como parceira na condução das políticas sociais e a sua "desfamiliarização"12 (MIOTO, 2008, p. 143).

Nesse seu artigo, a autora expõe como a família foi reconhecida pelos três projetos societários hegemônicos da história do homem, a saber: o liberalismo, o welfare state e o neoliberalismo. Mioto demonstra que o primeiro período vai representar a promoção da proteção social por meio de ações caritativas e solidárias que vinculam a família como agente natural do cuidado. Já durante os Estados de Bem Estar Social (uns com maior consolidação como na Europa nórdica e nos Estados Unidos e outros menos, como na América Latina e na Europa do Sul) a implementação de políticas sociais que visavam a ampliação dos direitos foi a tônica norteadora da ação estatal. Com a passagem para o neoliberalismo, a autora apresenta que houve uma "redescoberta" da família como instância de proteção, na perspectiva de recuperação de uma sociabilidade solidária (ibid.).

\subsection{Violência E A Culpabilização Dos Sujeitos}

A violência deve ser compreendida como um complexo social que se objetiva historicamente nas relações entre os sujeitos, portanto, pensar essa categoria sem seus determinantes e mesmo condicioná-la a único fator é desvinculá-la do seu processo de objetivação e estruturação do que José Fernando Siqueira da Silva aborda como "concreto pensado". Apontar a violência sob o enfoque do concreto pensado, diz o autor, é considerá-la em sua totalidade, transcender a aparência do fenômeno e buscar a trama constitutiva da realidade por meio de suas mediações (SILVA, 2007).

É preciso analisar que toda ação violenta se baseia em uma relação fundamental: a imposição ideológica do violentador sobre o violentado, isso significa dizer que para

\footnotetext{
${ }^{12}$ Desfamiliarização diz respeito ao abrandamento da responsabilidade familiar na provisão da proteção social, seja por meio do Estado ou do mercado.
} 
além das expressões aparentes da violência contemporânea - representada na criminalidade urbana - há de se avaliar que outras formas de violência permeiam o cotidiano: não seria a privação das necessidades humanas uma ação violenta contra o indivíduo? Perceber de que maneira alguns fatos são ideologicamente remontados como violentos e outros não, perpassa a análise da ordem social em que eles se afirmam, ou seja, a burguesa (idem).

Como anteriormente apresentado, o capitalismo monopolista de fins do séc. XX se apresenta como a forma mais acabada da ordem social baseada nas relações entre capital e trabalho. Caracteriza-se, pelo lado burguês, por meio da concentração do capital, a financeirização dos mercados, a redução dos custos da produção e o desenvolvimento tecnológico atenuante; pelo lado do proletário, acentua-se a divisão sócio-técnica do trabalho, a desregulamentação, precarização e flexibilização das relações trabalhistas. Todo esse contexto é fomentado pela ideologia neoliberal que prega o retrocesso na interpretação da questão social, isto é, a sua naturalização fatídica como parte integrante da estrutura capitalista não podendo, portanto, ser expurgada e devendo apenas ser amenizada. Nesse sentido, a compreensão da categoria violência vem sendo escamoteada por intelectuais burgueses que atribuem à pobreza e desigualdade social o fator causal das ações violentas - diga-se de passagem, essa foi uma posição adotada por muitos sociólogos na década de 50 e 60 (VALLADARES, 1991).

Em citação de Ianni feita por Silva, o autor avalia que:

\begin{abstract}
"Não se trata de simplificar a problemática da violência, como se ela coubesse no conceito, idéia ou interpretação. Vista em toda sua complexidade, em suas múltiplas manifestações coletivas e individuais, históricas e psicológicas, objetivas e subjetivas, é evidente que a violência é um acontecimento excepcional que transborda por meio de várias ciências sociais; revela dimensões econômicas, subculturais, objetivas e subjetivas." (IANNI apud SILVA, 2007:192).
\end{abstract}

Isso importa em mostrar que a adoção de uma única explicação para categoria violência do tipo "se [...], então [...]" permeia a implementação de ações cada vez mais coercitivas e preconceituosas para o "combate à violência". O Estado, no uso legítimo de sua força repressiva, investe montantes em polícia (mal preparada) e armamentos para que, assim, seja garantida a segurança. Mas segurança de quem? Para quem? E do quê se quer estar seguro? São questionamentos que podem ser levantados quando se 
analisa duas categorias apresentadas por Silva (2007): o binômio segurançainsegurança; e a higienização ou limpeza social.

Por binômio segurança-insegurança, o autor evidencia a complexa relação que se constrói entre polícia e bandidos. Em depoimentos apresentados em seu artigo, é perceptível como essas duas classes têm suas funções interpoladas: ora o bandido é fonte de confiança, ora o policial é fonte de medo. Isto porque, de forma velada ou não, a população pobre se vê alvo de ações violentas por parte das forças policiais que discriminam e criminalizam a pobreza (idem).

A categoria subseqüente, a da higienização ou limpeza social, se faz presente na forma perversa com que a classe dominante da sociedade compreende o "submundo do crime" - a classe a qual dele faz parte, o material descartável ao capital - e o enfrenta por meio de ações concernentes ao "eixo repressão-eliminação". Trata-se cada vez mais de desvincular o foco da real dificuldade da ordem social capitalista, qual seja: o enfrentamento da questão social e suas expressões, em prol de um puro e simples banditismo e caos social (idem).

Em referência aos trabalhos de Baronti (1978) sobre as implicações da violência no que tange a família, Mioto (2008) afirma

A violência nas suas mais diversas manifestações, embora se realize no âmbito do convívio social, é implícita às relações de produção sob a lei da acumulação capitalista. Portanto, em primeiro lugar, está a violência econômica. Porém, essa violência não aparece no em que é produzida, mas se explicita através dos seus efeitos, tornando a família um palco privilegiado de manifestação desses efeitos e concomitantemente a absorção e desativação dos conflitos sociais (MIOTO, 2008, p.132).

A violência, a partir de pressupostos neoliberais vai sensivelmente responsabilizar a família pela sua evitação. Segundo essa perspectiva, a família como provedora do bem-estar tem a obrigação em cuidar e tratar de seus componentes para que esses sigam as regras e se estabeleçam na sociedade como indivíduos sãos e trabalhadores. O papel do Estado, nessa orientação, restringe-se apenas a uma ação paliativa de trancafiamento daqueles que não se integraram na sociedade e, para além disso, a responsabilização (leia-se estigmatização) daquela que não cumpriu a sua função disciplinadora: a família, especialmente na figura da mulher, como se verá mais adiante. 
Por meio do exposto acima, verifica-se que a categoria violência vem sendo abordada de forma ahistórica e inconcreta. Correlacionar violência e pobreza sem abordar a estrutura que as permeia, é desvirtuar o foco da atenção pública. A violência nos moldes atuais não é mais do que a (re)significação e constante reprodução da ideologia que une pobres à classes perigosas. Nesse olhar, a família vai ser, juntamente com o "bandido", a maior responsável pelo "descuido" na educação dos filhos. 


\section{DO ESTADO SOCIAL AO ESTADO PENAL}

Retomando a história do capitalismo contemporâneo, observa-se que a partir da década de 1970 se empreende a crise do capitalismo contemporâneo. Tida por muitos autores como uma crise forjada, é bem verdade que o capital vinha decrescendo sua margem de lucro em prol de um welfare state que para além de produzir maior proteção social dos cidadãos também foi a forma encontrada por esse sistema produtivo para não sucumbir a seu próprio desaparecimento em decorrência da crise de 1930. Os chamados anos dourados do capitalismo que vai de 1940 a 1960 representaram uma maior intervenção do Estado no âmbito, não somente social, mas também econômico. Mecanismos de regulação da economia foram impressos a fim de que se criasse um sistema ideal de produção e reprodução capitalista, afastando os fantasmas da superprodução e agregando maior demanda aos produtos comercializados.

Para custeio desse programa estatizante, trabalhadores e capitalistas tiveram que contribuir para o seu financiamento. O capital que até o momento estava "acostumado" a sua dita auto-regulação sem qualquer preocupação com a parte mais importante do seu processo produtivo, qual seja o trabalhador, se viu obrigado a "ceder" parte de seu patrimônio econômico para a manutenção do próprio capital. Por outro lado, o acirramento da questão social e o crescimento do pauperismo da classe trabalhadora também serviram de força motriz nessa mudança estrutural. As greves trabalhistas e feministas das décadas de 1930 em diante que além de requisitarem melhores condições de trabalho, já chamavam atenção para o trato de todo um conjunto de ações no campo social, vide as caixas de previdência, a questão dos hospitais, entre outros.

Os Estados de Bem-Estar Social vão nessa medida representar essa dialética de necessidade de implementação de um programa restitutivo do capitalismo e da promoção da proteção social da classe trabalhadora por meio da chamada social democracia. Na mesma medida em que esses Estados Sociais surgem como uma demanda do modo de produção capitalista - que não se exclua, como dito anteriormente, o preponderante papel exercido pelas lutas trabalhistas para o surgimento destes Estados - a sua substituição por um projeto societário retrógado em termos de proteção social, com nítidos ranços da era pré-welfare state, demonstram também terem 
sido forjados no âmbito desse mesmo sistema produtivo como forma de reposição dos "lucros perdidos" em face dessa reconstrução pós-crise e que não teria impedido um segundo momento de crise que irradiava nos alvores da década de 1970. E para concretização deste objetivo, era necessário se retirar, expurgar essa ideologia de cidadania social do proletariado, era preciso se (re)tomar por direitos somente os civis e políticos - com também menor representação deste último. A maneira encontrada, então, para se promover essa catarse social foi a partir da criação da ideologia de uma pretensa insegurança.

Segundo Arguëllo (2005), em face do capitalismo não ser capaz de achar soluções coletivas para lhe dar com os problemas que aviltavam o sistema, se propôs, então, ao desvio de foco das incertezas de garantias de meio de vida da população para uma preocupação destinada com a segurança pública. A autora em citação de estudos de Bauman (2000) vai apresentar que além da crise econômica, as crises existenciais e políticas - que são na verdade fenômenos de um mesmo problema global - formarão um quadro que em tudo coopta para construção de um Estado Penal em contraposição ao Estado Social:

Essa é uma das razões do triunfo das diretrizes neoliberais na medida em que prossegue desmantelando as instituições políticas que poderiam em principio opor resistência à liberdade do capital: dissemina uma insegurança (ansiedade) difusa, de modo que a natureza mesma dos problemas a serem enfrentados, como assinala Bauman, constitui-se um impedimento para soluções coletivas: '[...] pessoas que se sentem inseguras, preocupadas com o que lhes reserva o futuro e temendo pela própria incolumidade não podem realmente assumir os riscos que a ação coletiva exige'. Isso é o que torna ainda mais intricada a situação e se traduz a crise existencial (Unsicherheit: incerteza, insegurança e falta de garantia) (ARGUËLLO, 2007:4).

Essa estruturação de uma ideologia do medo vai permear o controle social da população caracterizada como supérflua ao mundo do trabalho, ou seja, parafraseando Medeiros (2007), o surplus excedente da força de trabalho gerado a partir dos anos 1970 pelo capitalismo vai gestar formas de supervisão balizadas em duas classificações: a) aqueles considerados como social junk ${ }^{13}$ serão geridos pela política de assistência social

\footnotetext{
${ }^{13}$ Expressão cunhada pelo criminólogo marxista Seven Spitzer para designar a parcela do subproletariado considerada inofensiva e, portanto, passível de controle por meio de ações punitivas "brandas" de alistamento em programas sociais estigmatizadores do estado moderno.
} 
que, através da crescente estigmatização, os punirá; e b) os adjetivados como social dynamite $^{14}$, por sua característica explosiva, serão judicializados como criminosos em processos penais.

Em termos de penas, essa nova ideologia se encerra no retorno a antigas prática punitivas. Cada vez mais se assiste ao retomada dos castigos físicos, a incitação a práticas de uma sociedade baseada no workfare. O significado da pena também terá suas modificações com o decorrer do processo histórico. Como se verá adiante, o suplício foi uma das primeiras formas punitivas utilizado na Idade Média - a construção da pena como um espetáculo garantia o caráter exemplificativo da ação. Já no início do capitalismo em fins do século XVII a necessidade de formação de um exército de reserva vai orientar as práticas penais no sentido da instauração de uma política de disciplinamento dos corpos, os presos eram considerados como uma mão-de-obra capaz de ser utilizada a baixo custo operacional, visto que o estigma de preso valorava negativamente o preço da sua força de trabalho. Com o advento do neoliberalismo e a desestruturação do mercado de trabalho, a pena ganha uma nova conotação que podemos considerar ser a unificação dos dois períodos precedentes, isto é, a representação da cadeia como um local desumano retoma o caráter exemplificativo da Idade Média, ao passo que, a utilização do trabalho do recluso ao custo inferior a um salário mínimo ${ }^{15}$ e a sua não submissão a Consolidação das Leis do Trabalho também incute o retorno às práticas punitivas do século XVII em diante.

Nessa perspectiva de aprofundamento da questão penal no mundo contemporâneo, Wacquant (2001), ao fazer um estudo da temática nos países centrais,

\footnotetext{
${ }^{14}$ Expressão cunhada pelo criminólogo marxista Seven Spitzer para designar o surplus potencialmente explosivo e perigoso para ordem devendo, portanto, serem tratados com o devido rigor repressivo do sistema penitenciário.

${ }^{15}$ Art. 29. O trabalho do preso será remunerado, mediante prévia tabela, não podendo ser inferior a 3/4 (três quartos) do salário mínimo.

$\S 1^{\circ} \mathrm{O}$ produto da remuneração pelo trabalho deverá atender:

a) à indenização dos danos causados pelo crime, desde que determinados judicialmente e não reparados por outros meios;

b) à assistência à família;

c) a pequenas despesas pessoais;

d) ao ressarcimento ao Estado das despesas realizadas com a manutenção do condenado, em proporção a ser fixada e sem prejuízo da destinação prevista nas letras anteriores (BRASIL, 1984).
} 
aponta a adoção de duas doutrinas gestadas em Manhattan nos Estados Unidos: a da "tolerância zero", inventariada por Charles Murray, que dá plenos poderes à policiais e juízes para tratarem da "pobreza que incomoda" - negros, desempregados, mendigos, sem-teto, vadios em geral; e a da "broken windows”, formulada por James Q. Wilson e George Kelling os quais afirmavam que a proliferação das incivilidades seria meio caminho andado para o arrefecimento da delinqüência. Em conjunto essas duas teorias criadas nos Estados Unidos vão rodar o mundo todo atrás de adeptos. Interessante é que o autor faz menção a aplicação da "tolerância zero" em Brasília, ao citar que o então governador Joaquim Roriz a faria por meio da contratação de 800 policiais civis e militares em resposta a uma onda criminosa que deveria ser combatida. Tendo sido o governador alertado de que isso causaria uma superlotação dos presídios brasilienses os quais já não comportavam mais presos à época, este teria dito que seria necessária, tão somente, a construção de novos presídios.

$\mathrm{O}$ autor indica que o processo de encarceramento que se vive nos dias atuais segue cinco tendências: i) hiperinflação carcerária com o aumento aviltante da população reclusa, a chamada expansão vertical do sistema; ii) a expansão horizontal da rede penal por meio do crescimento da população de alguma forma ligada a Justiça seja através das penas alternativas, das prisões domiciliares ou dos benefícios de Livramento Condicional (Wacquant demonstra que esse processo possui íntima relação com a tipificação de novos delitos); iii) crescimento excessivo dos gastos da administração pública com o setor penitenciário, não que isso signifique um maior gasto na manutenção das condições mínimas do recluso, mas sim, o aumento do aparato coercitivo físico (mais policiais e agentes penitenciários para as prisões; construção de novas unidades; cursos de aperfeiçoamento de recursos humanos, etc.); iv) o ressurgimento da privatização das cadeias, um maior número de celas em prisões privadas e a sua prosperidade como indústria; v) a política de "ação afirmativa" carcerária: mais negros são presos, o que o autor coloca como um "escurecimento" contínuo da massa carcerária (ibidem).

Com essas cinco notas acerca do sistema penitenciário, Wacquant conclui que a retirada do Estado do campo social não significa a redução do seu escopo de atuação, pois, com base na legitimidade (por parte dos capitalistas) do uso dos aparelhos repressivos do Estado, este adotará intervenções muito mais nessa linha da coerção e 
controle como forma de manutenção hegemônica do sistema a que serve. Isto implica em vários espaços da reprodução social, a saber: compreensão do que vem a ser o crime; de quem o comete; e qual a melhor solução para o seu "tratamento". Desvinculase a violência do seu contexto estrutural, resignificando-a em termos de "capacidade cognitiva" do ser humano, do seu quociente intelectual, naturaliza-se, portanto, a criminalidade. O binômio pobreza-violência toma o primeiro por causa e o segundo como conseqüência, em uma ideologia transfigurada que promove a inversão da ordem: a pobreza não é causada por uma violência estrutural contra o cidadão, mas sim a violência é que é causada pela miséria.

\subsection{Ensaio Sobre Uma Instituição Total: A Prisão}

A prisão como tema de estudos sociológicos é apresentada aqui a partir da perspectiva de três autores, sendo eles: Erving Goffman (1997), sociólogo canadense, o autor do livro Manicômios, Prisões e Conventos; Michel Foucault (1975), filósofo francês que traz suas contribuições por meio do livro Vigiar e Punir - Nascimento da Prisão; e Philippe Combessie (2001), sociólogo francês aqui representado pela resenha de Sociologia da Prisão executada por Isabel Pojo do Rego (2004), doutora em Sociologia pela Universidade de Brasília - UnB.

Antes de caracterizarmos a instituição tomada aqui por base como total, faz-se necessário identificarmos o próprio termo instituição. Segundo Foucault (1975), a instituição é um espaço de coerção em que o poder é exercido por meio do saber,

produz-se um discurso ideológico caracterizado como "verdadeiro". Na concepção de Goffman (2001), as instituições são estabelecimentos sociais em que ocorre atividade de determinado tipo, elas conquistam parte do tempo e do interesse de seus integrantes, lhes proporcionando algo de um mundo.

A instituição total é uma expressão utilizada por Goffman (2001), apesar de não ter sido cunhada pelo autor, para caracterizar "um local de residência e trabalho onde um grande número de indivíduos com situação semelhante separados da sociedade mais ampla por considerável período de tempo leva uma vida fechada e formalmente 
administrada" (idem, p. 11). O autor assinala que todas as instituições têm tendências de serem mais ou menos "fechadas". Esse seu caráter, que também pode ser traduzido como total, é representado pela barreira à relação social com o mundo externo e por proibições à saída, às vezes mediadas pelo próprio ambiente físico com portas fechadas, paredes altas, arame farpado, fossos, águas, florestas e pântanos.

Goffman propõe cinco tipos de instituições totais: i) instituições criadas para cuidar de pessoas incapazes e inofensivas; ii) locais para cuidar de pessoas consideradas incapazes de cuidar de si mesmas e que são também uma ameaça à comunidade, embora de maneira não-intencional; iii) estabelecimentos organizados para proteger a comunidade contra perigos intencionais, e o bem-estar das pessoas isoladas não constitui problema imediato; iv) instituições criadas para realização de alguma tarefa de trabalho, que se justificam apenas através dos fundamentos instrumentais; v) locais que servem para refúgio do mundo, algumas também utilizadas para instrução religiosa. A que nos interessa diz respeito ao estudo do terceiro tipo de instituição total, exemplificados pelas cadeias, penitenciárias, campos de prisioneiros de guerra, campos de concentração (idem).

$\mathrm{Na}$ primeira parte de seu livro, Goffman (1997) apresenta algumas características comuns das instituições totais, além das perspectivas do mundo do internado, do mundo da equipe dirigente além das chamadas cerimônias institucionais momento de contato desses dois grupos. Inicialmente, o autor destaca que o local para a realização das atividades cotidianas, como trabalho, lazer e vida íntima é o mesmo, sendo todos esses aspectos realizados em bandos, a partir de um roteiro racionalmente pré-estabelecido e sob a vigilância de uma mesma autoridade. Frise-se que o papel dessa autoridade não é orientar ou inspecionar periodicamente, mas fazer com que todos executem o que foi exigido.

Antes de passar para a análise de cada grupo que compõe a instituição total, o autor sinaliza que cada agrupamento concebe o outro de maneira estereotipada e hostil: da parte dos internados, os dirigentes são mesquinhos e arbitrários; e da parte dos dirigentes, os internados são amargos e não merecedores de confiança. Ao apresentar o mundo do internado e dos dirigentes, Goffman destaca que o internado passa por um processo de mortificação do eu a partir do momento da iniciação na instituição, 
identificada como "as boas-vindas", incluindo desde processos de admissão, testes de obediência, exposição contaminadora, etc. Outro aspecto interessante é do sistema de castigos e privilégios que promove a "reorganização pessoal" do indivíduo segundo o modelo da instituição total.

Com relação às cerimônias institucionais, o autor destaca que se trata de "um conjunto de práticas institucionalizadas - seja espontaneamente, seja por
imitação - através dos quais os internados e a equipe de dirigentes chegam a
ficar suficientemente perto para ter uma imagem um pouco mais favorável do
outro, e a identificar-se com a situação do outro" (Idem, p. 85).

Essas ações, por vezes, objetivam a legitimação dessas instituições e suas práticas. Quando uma autoridade, familiares ou convidados visitam a instituição é realizado todo um processo de "maquiagem" da realidade visando assim o consentimento para manutenção dessa forma de exercício de poder, o que o autor caracteriza como "exibição institucional". Por parte do internado, essas cerimônias são entendidas como um dos poucos momentos em que se pode fugir da rotina cotidiana da instituição e ter acesso a privilégios, porém é preciso lembrar que mesmo nesse ambiente de aparente harmonia social, os que apresentarem más condutas são castigados.

O autor finaliza a sua abordagem trazendo alguns aspectos para serem estudados mais adiante como a estratificação dentro desses próprios agrupamentos, e a necessidade de certa impermeabilidade institucional, que é caracterizada pelo baixo nível de aceitação do status social que os indivíduos possuam fora da instituição, além do trato do estigma dos internados após saírem dessas instituições e retornarem para a sociedade.

Na obra Vigiar e punir, Foucault (1996) investiga o direito penal nos regimes absolutistas europeus, contrastando-os com o modo operado nos regimes democráticos que se consolidaram na Europa a partir do final do século XVIII. Descrevendo o modo como os delitos penais foram (e são) assimilados historicamente, Foucault demonstra o contraste de duas formas de exercício de poder, apresentadas no modo de tratamento do criminoso: nos regimes absolutistas, o poder se exercia e se reafirmava por meio do severo exercício da punição; no mundo emergente pós-revolução francesa até os dias 
atuais, a modalidade do poder objetiva o vigiar e disciplinar, sendo denominada, portanto, de sociedade disciplinar.

No regime absolutista, encontramos um direito penal que é exercido pela autoridade de um poder judiciário central, subordinado à figura do rei. Nessa perspectiva, todo delito praticado é, acima de tudo, ato ilícito que afronta ao ilimitado poder real. Por isso, uma característica central desse período é a prerrogativa do suplício como forma de punição e manutenção do poder. Por suplício entende-se uma pena corporal dolorosa com requintes de atrocidade, cujo grau de crueldade variará de acordo com o delito praticado. Foucault destaca que o suplício era antes de tudo um grande espetáculo, momento em que a autoridade do rei era reforçada por uma aterrorizante demonstração de força. Além da punição, o suplício tinha a finalidade de reavivar nas mentes dos súditos o que ocorria com qualquer um que ousasse desafiar a vontade do soberano.

A partir do século XVIII, filósofos e juristas começam a se manifestar contra o caráter desumano do suplício. Surge, então, a idéia de que toda e qualquer forma de punição poderia ser amenizada, além de criar mecanismos que proporcionassem garantias de que o menor número possível de delitos fosse praticado. Surge o que Foucault chama de sociedade disciplinar, caracterizada como um modo de organizar o espaço, controlar o tempo e obter um registro ininterrupto do indivíduo e de sua conduta. No que tange ao exercício do poder, essa sociedade se caracterizaria por implantar o "poder panóptico", derivado do Panapticon do jurista britânico Jeremy Bentham, que é o modelo de edifício com celas dispostas em torno de um círculo e ao centro uma torre elevada. Seu desenho previa que o vigia colocado na torre central podia ver todos os movimentos daqueles trancados nas celas, sem que estes o pudessem ver.

Foucault observa que o modelo de seqüestro de delinqüentes proposto por Bentham caracterizaria o que na sociedade contemporânea é denominado vigilância, o pleno controle e a correção dos indivíduos. Ela representa um novo ponto de vista do poder que ao invés de punir um indivíduo que pratique qualquer ato ou infração, tem suas ações previstas, antevistas pelo sistema bem como torna possível também a correção de tendências desajustadas, reorientando-as na direção estipulada pelo poder 
panóptico. Assim, esse poder se legitima por meio do surgimento de instituições que referendam o modelo do Panapticon, tais como: a fábrica, a prisão, o hospital, a escola.

De acordo com o autor, o poder panóptico se efetiva mediante o cumprimento de algumas funções: o controle do tempo, o controle dos corpos e a instauração de uma polimorfia do poder que inclui um braço epistemológico. Nas instituições panópticas, o indivíduo é seqüestrado e abstraído do tempo de sua vida. Seu caráter é moldado por meio de um jogo de castigos e recompensas. Seu corpo é confiscado pela sociedade, que será moldado de acordo com a função social que ocupará dentro do sistema de produção. O controle do tempo e do corpo é instaurado graças a uma polimorfia de poderes. Assim é que um poder econômico claramente se instaura com a instituição das fábricas, e, atrelado a este, um poder político. Esses poderes se articulam a um poder judiciário, o qual impõe normas, dá ordens e toma decisões.

Por fim, o poder panóptico permite o surgimento de uma ciência própria. Foucault atribui a seu exercício, as circunstâncias que tornaram possível o surgimento das ciências humanas. Encontramos em todas as instituições disciplinares a produção de um conjunto de saberes. Este se delineia em dois sentidos: dos indivíduos e sobre os indivíduos. $\mathrm{O}$ autor interpreta o conhecimento como uma grande invenção, ferramenta indispensável à legitimação de uma forma de poder. 


\section{JUDICIÁRIO: CONTEXTO E ESTRUTURA}

O surgimento do Poder Judiciário tal conhecemos hoje remonta à origem do sistema capitalista de produção. Primeiramente, porém, é necessário reconhecer que a Justiça como uma instituição dos homens surgiu muito antes da constituição de um Poder específico, haja vista que estudos comprovam que nas sociedades antigas a função de "Juiz" sempre fora exercida por alguém, seja o patriarca da família, seja o chefe da tribo. Ulteriormente, na Grécia Antiga, os "tribunais" já eram espaço consolidados de julgamento, cita-se, por exemplo, os tribunais da Atenas como o Areópago, o Paládio, o Delfino, o Pritaneu etc.. Em Roma a magistratura era exercida pelos pretores que se incumbiam de aplicar a justiça; em certas ocasiões tais funções eram atribuídas ou ao Senado ou ao cônsul. É nessa época que a retórica surge como artífice principal no poder de persuasão do julgador.

Ao longo da Idade Média, antes mesmo da constituição dos Estados Nacionais, a função de Juiz passa a ser exercida, durante o feudalismo, pelo Senhor feudal que, tendo sob a sua "responsabilidade" toda uma gama de indivíduos em regime de servidão, outorga suas leis de maneira ditatorial. O não cumprimento dessas leis era passível de punição com requintes de crueldade: enforcamento, decapitação, separação dos membros, etc.. A partir do surgimento dos Estados e dos regimes absolutistas, o rei passa a ser o grande Julgador das desobediências de seus servos ${ }^{16}$. O déspota autoritário era considerado a lei e a ordem na antiga sociedade medieval e, assim como nos feudos, qualquer forma de contravenção da lei era punida com rigor.

Após a superação deste período e a definitiva entrada na Era Moderna, assiste-se a toda uma transformação da sociedade com o surgimento do capitalismo. Antes mesmo, toda a ideologia gestada durante as Revoluções Inglesa e Francesa por intelectuais como Thomas Hobbes, Jonh Locke, Denis Diderot, Nicolau Maquiavel,

\footnotetext{
${ }^{16}$ A figura do Rei não surge como novidade, porém a sua preponderância como chefe de Estado é que vai torná-lo uma importante peça no cenário político. Como apresentado, anteriormente, os chefes dos feudos eram os grandes responsáveis pela manutenção da ordem em seus latifúndios e não o rei, que já era figura patente nas sociedades até então.
} 
Charles de Montesquieu, entre outros, dará arcabouço para a materialização desse novo modo de produção. Nas obras de todos esses autores é apontada a necessidade da liberalização da propriedade privada e da promoção de formas de asseguramento desse direito por meio de leis. É nesse intento, que a formulação de uma Justiça mais rígida (e um tanto desigual do ponto de vista que separa os indivíduos entre detentores e não detentores de propriedade privada) e institucionalizada no Estado contra aqueles que infringissem qualquer direito dos proprietários é concebida por meio da separação dos poderes em Executivo, Legislativo e Judiciário com clara definição dos papéis a serem executados por cada um.

A partir dessa abordagem histórica, José Eduardo Faria (1994), estudioso da Sociologia Jurídica e de Metodologia da Ciência do Direito, ajuda-nos a entender o papel do Poder Judiciário no Brasil contemporâneo. O autor suscita três desafios que foram objeto de polêmica na compreensão da função de mediação do Judiciário em face das novas relações de produção econômica e política pós-Constituição de 1988: 1) os tribunais começaram, cada vez mais, a operar em casos de natureza tributária, reduzindo a capacidade de execução de políticas econômicas pelo Estado; 2) os movimentos populares constituem-se como importantes atores na defesa de direito, principalmente humanos, com o propósito de judicialmente reivindicá-los para as maiorias marginalizadas; 3) a postura tradicional que a maioria dos juízes ainda se utiliza na interpretação dos litígios, contrapõe-se a uma minoria que opta por uma abordagem mais politizada, crítica e com grande sensibilidade social.

Inicialmente, Faria (idem) propõe um entendimento da sociedade brasileira como um todo. Descreve o Brasil como um país, que desde os anos 70, pode ser considerado industrializado e de caráter predominantemente urbano, em que as classes operárias, média e rural atingiram um nível mínimo de organização em prol de seus direitos; em contrapartida, apresenta-se como uma sociedade de dualismos: pobreza urbana massiva e bolsões de riqueza. $\mathrm{O}$ autor coloca que esses dualismos são frutos de três crises estruturais: no plano sócio-econômico, crise de hegemonia dos setores dominantes; no plano político, crise de legitimação da representatividade; e no plano jurídico-institucional, uma crise da matriz organizacional do Estado. Numa tentativa de interligação dos três planos, afirma-se que as "condições sócio-econômicas, gerando demandas para as quais as instituições não têm condições de oferecer respostas rápidas 
e eficientes, terminam por afetar a própria estrutura organizacional do Estado" (FARIA, 1994:13).

A crise, em um plano mais geral, tem sua origem no próprio modelo de desenvolvimento burocrático-autoritário adotado pelo governo pós-64. Isso significava medidas de contenção de reivindicações sociais que dificultassem a execução programática da política econômica, neutralizando canais tradicionais de participação política, intervindo nos sindicatos e adotando políticas trabalhistas que restringiam o aumento da massa salarial. Porém a partir de 1974, com o primeiro choque do petróleo e a crescente crise financeira global, esse modelo de desenvolvimento começou a apresentar seus primeiro sinais de colapso: o Estado que havia assumido o papel de empresário, criando agencias burocráticas, empresas públicas e gastos incontroláveis, acabou por comprometer a sua própria racionalidade, reduzindo a liberdade de agir em face do novo contexto. Já nos anos 80, com o definitivo esgotamento do modelo burocrático-autoritário, as regiões metropolitanas se tornaram espaço de conflito generalizado, isto porque, continuando o Estado a dar prioridade a projetos ambiciosos nessas regiões - mobilizando contingentes de mão-de-obra desqualificada que ao concluírem as obras deixavam um rastro de tensão social e marginalidade econômica ampliou a crise de sua própria legitimação (FARIA, idem).

No plano jurídico-institucional, todo esse contexto de conflitos de interesses em uma sociedade em transformação, exponenciou as tradicionais dificuldades enfrentadas pelo Judiciário para enfrentar as novas configurações históricas, conduzindo a uma progressiva desconfiança com relação a objetividade das leis, como critério de justiça, quanto na sua efetividade, como instrumento de regulação e direção da vida sócioeconômica. Gera-se, então, uma cultura da impunidade e da ilegalidade: os códigos abstratos e irreais e sua violação sistematicamente tornaram-se parte da regra e não da exceção, expressando, assim, a falência das instituições jurídico-judiciais, que anacrônicas não teriam conseguido se renovar. Um sistema legal caracterizado por ser ineficaz, que limita o papel arbitral em um contexto social tão contraditório, e os limites tanto profissionais - criatividade e flexibilidade interpretativa das leis - quanto institucionais de renovação desses códigos, são motivos que impedem o verdadeiro cumprimento das sentenças engendrando a imagem de "anomia" jurídica perante a sociedade (FARIA, idem). 
Todas essas questões apontam para uma necessidade de renovação da cultura jurídica urgente, revendo assim as funções exercidas pelos operadores do direito que, em um contexto de crise, são demandados a atuar com forças contrárias até então inexistentes que abrem caminho para impasses jurídicos e institucionais. As reflexões teóricas sobre o direito como instrumento de promoção social, observada a heterogeneidade da sociedade e o caráter intervencionista do Estado, apontam para dois objetivos básicos: a) explicar como as formas jurídicas influenciam e são influenciadas pela organização das relações de produção econômicas e políticas; e b) demonstrar como a pretensa neutralidade e objetividade configuram-se como empecilho no conhecimento de uma sociedade permeada de conflitos sócio-econômicos. Pretende-se considerar as leis e os códigos não como meros procedimentos ahistóricos, mas como vinculados ao saber de seu tempo: o sistema jurídico faz parte da formação social determinada (FARIA, idem).

\subsection{O Tribunal De Justiça Do Distrito Federal E Territórios}

Segundo o sítio do Tribunal de Justiça do Distrito Federal e Territórios, a instituição tem por missão: "proporcionar à sociedade do Distrito Federal e dos Territórios o acesso à Justiça e a resolução dos conflitos, por meio de um atendimento de qualidade, promovendo a paz social”. Já a visão do Tribunal é buscar o reconhecimento da sociedade como uma instituição de excelência na prestação de serviços de forma eficiente por meio de recursos humanos capacitados, gestão estratégica e utilização de inovações tecnológicas.

Segundo Faria (2001), o Tribunal de Justiça do Distrito Federal e Territórios (TJDFT), integrante do Poder Judiciário brasileiro, tem por finalidade: “a) uma função instrumental (dirimir conflitos); b) uma função política (promover o controle social) e; c) uma função simbólica (promover a socialização das expectativas à interpretação das normas legais)" (p. 9). O TDFT é um órgão que tem por objetivo julgar os conflitos e dissídios entre os cidadãos, menos entres estes e o Estado e o próprio Estado; sendo passível de recurso no Superior Tribunal de Justiça - STJ, ou no Superior Tribunal Federal - STF. 
Segundo Souza (2004), o surgimento da justiça do Distrito Federal e Territórios data da fase republicana provisória brasileira, ainda quando o Brasil era denominado de Estados Unidos do Brasil, sofrendo alterações e se complexificando com o decorrer do tempo. Já neste período a organização judiciária brasileira contava com a figura do Juiz, posteriormente, com a complexificação da Justiça brasileira, surgem outros elementos jurídicos, como o Tribunal de Júri, Tribunal de Imprensa, o Corregedor de Justiça e o Conselho de Justiça.

A partir da transferência da capital para o Distrito Federal em 1960, a lei n 3754 dispôs sobre a nova organização judiciária do Distrito Federal, compondo-se de 07 desembargadores e mantendo a estrutura anterior. Com a Constituição de 1988 dá-se autonomia para que os órgãos do poder judiciário, em nível federal e estadual, elaborassem normas e leis que regulamentassem o funcionamento e a organização dos seus órgãos jurisdicionais e administrativos, sendo que a justiça do Distrito Federal passou a ser organizada pela Lei de Organização Judiciária do Distrito Federal, o Regimento interno do TDFT e o provimento da corregedoria (ibidem.).

Atualmente, o TJDFT é composto de Primeiro e Segundo de jurisdição. A Magistratura de Primeiro Grau compõe-se de Juízes de Direito e Juízes de Direito Substitutos. A justiça de Primeiro Grau compreende a Vara de Execuções Penais (VEP) - onde está inserida a Seção Psicossocial - com competência em todo território do Distrito Federal. A VEP possui um Juiz de Direito e três Juízes de Direito Substitutos, responsáveis por julgar, monitorar e acompanhar toda execução penal no Distrito Federal.

Segundo a Lei de Execução Penal em seu artigo 66, além da Vara de Execuções Penais, outra instituição responsável pela execução penal é o Juízo da Execução, que possui por competência aplicar aos casos julgados, lei ulterior que favoreça o réu, declarar a extinção da punibilidade, decidir sobre a soma ou unificação de penas, progressão ou regressão nos regimes, detração ou remição da pena, suspensão condicional da pena, livramento condicional, e com isso, zelar pela aplicação correta da lei e do cumprimento da pena e da medida de segurança. 


\section{SERVIÇO SOCIAL NO ESPAÇO SOCIOJURÍDICO}

Apresentada as configurações em que se inscreve a atuação profissional da Assistente Social no contexto de Justiça, cabe agora, nos encaminharmos para uma análise mais aprofundada desse campo de trabalho. Posto esse objetivo, este capítulo procura, primeiramente, interpelar o significado da utilização dos termos trabalho, processos de trabalho, atuação e intervenção profissional como categorias de referência ao exercício profissional da Assistente Social. Em seguida, efetivamente, introduzir-se-á o foco desse capítulo, apresentando, para além do regate histórico necessário sobre a temática sóociojurídica, as perspectivas atuais desta dentro do Serviço Social.

A categoria trabalho tem sua definição baseada nos estudos marxianos. Marx, ao propor uma análise histórica das sociedades com base no processo produtivo, inscreve o trabalho como condição eterna do homem, a partir do momento que este é produtor e produto historicamente constituido. Em 1923, Lukács, a partir dos Manuscritos de 1844 escritos por Marx, apresenta o trabalho como categoria fundante do ser social, ou seja, numa perspectiva ontológica marxiana de construção do sujeito social, o trabalho nada mais é do que a transformação da natureza pelo homem em prol de sua própria reprodução social. Lessa (2000) aponta que "por meio do trabalho os homens não apenas constroem a sociedade, como também se constroem enquanto indivíduos” (p. 8).

Nesse sentido é preciso fazer uma pequena apreciação do processo produtivo referendado em seus mecanismos de produção e reprodução. Segundo Granemann (1999), o ato de produzir está relacionado diretamente a relação do homem com a natureza; já a reprodução se insere nos atos não somente relativos a vida material e biológica do ser humano, mas também àqueles que o fazem dar continuidade a sua vida social, a um dado grau de sociabilidade de participação na civilização. Observa-se, portanto, que a produção e a reprodução são duas partes de um mesmo processo, no qual uma não existe sem a outra, imbricadas na totalidade e singularidade histórica.

Retomando os estudos de Lessa e fazendo a interface com o Serviço Social, o autor aponta que este é uma mediação singular da reprodução social e, nesta medida e sentido, sendo um complexo distinto e insuperavelmente articulado ao trabalho. Adepto da teoria de que Serviço Social não é trabalho e muito menos processo de trabalho, 
concebendo essas duas categorias de forma estrita e imutáveis, Lessa inscreve a práxis profissional no âmbito da reprodução das relações entre os homens e não entre estes e a natureza. Segundo o autor

(...) o resultado da práxis é o desencadeamento de novas posições teleológicas por outros indivíduos; no outro caso, é o desencadeamento de 'nexos causais' na esfera da causalidade. Esta diferença fundamental entre os atos de trabalho e as práxis preparatórias dos atos de trabalho reflete a distinção fundamental da função social de cada um: o trabalho produz a base material da sociedade, as outras práxis atendem às necessidades socialmente postas para que os atos de trabalham possam se efetivar na forma historicamente necessária à cada sociedade, a cada momento (LESSA, 2000, p. 24).

Pode-se afirmar que com base na argumentação do autor somente alguns "trabalhadores" efetivamente trabalham na sociedade, enquanto que outros estariam renegados a um segundo plano de reprodutores deste sistema. Questiona-se, porém, se, a partir desse apontamento, ainda seria possível se falar em luta dos trabalhadores, visto que com o decorrer do processo histórico, o trabalho produtivo vem significativamente diminuindo seus postos ao passo que o chamado setor de serviços cresce em números de contratados.

Uma segunda perspectiva é a corroborada pela autora Sara Granemann (1999) que apresenta a práxis profissional no âmbito do trabalho produtivo ou improdutivo. Segundo a autora, o Serviço Social opera como trabalho produtivo quando participa da geração de artifícios para a extração da mais-valia, ou seja, apesar da atuação profissional não operar no "chão da fábrica", este ainda assim é gerador de riqueza, fazendo parte do trabalho coletivo. Em se tratando de trabalho improdutivo, Granemann aponta que este é realizado na medida em que os esforços empenhados não agregam valor ao produto final. Esse é o caso de um assistente social que é chamado a desenvolver uma política pública, visto que o seu esforço não agrega valor ao Estado, por não cumprir o objetivo de transformar o capital, destinando-se ao consumo individual.

Partindo para uma última análise, averigua-se as produções que tratam do Serviço Social como processo de trabalho. Segundo Babosa et al (1998), a partir das obras marxianas, falar em processos de trabalhos significa retomar o conceito de trabalho na perspectiva de sua efetivação se dar por meio de processos, isto é, a 
transformação da natureza por meio do dispêndio de energia do homem para realizá-la implica em uma série de micro relações processuais de formação de valor no processo de produção capitalista. Os autores apontam que "o trabalho do assistente social se dirige, no âmbito da divisão do trabalho, para a obtenção de efeitos específicos sobre as práticas sociais" (p. 113). Tendo por base a mudança de práticas sociais, a atuação do assistente social alcançará seu fim por meio dos seus processos de trabalho que são varáveis e mutáveis.

A partir dessa abordagem, o trabalho do Assistente Social no campo Sóciojurídico não se constitui uma peculiaridade da atuação profissional, no sentido que, assim como não existe um Serviço Social da Saúde, ou da Assistência Social ou de qualquer outro espaço ocupacional, o Serviço Social no Sócio-jurídico também deve ser interpretado como um campo de intervenção dentro do marco do trabalho do Assistente Social. Isso equivale a dizer que, apesar dos espaços ocupacionais, o trabalho do Assistente Social é um somente: atuar no enfrentamento da questão social e suas expressões; como apontado acima, as especificidades da atuação se configurarão em seus processos de trabalho, ou seja, nas mediações dos pressupostos técnico-operativos e teórico-metodológicos.

Explicitado esse ponto, Fávero em apresentação na Plenária do Simpósio Mineiro de Assistentes Sociais, CRESS - 6 ${ }^{a}$ Região, no dia 18/05/2007, ao abordar o tema da atuação profissional nesse campo, afirma que

"O termo campo (ou sistema) sóciojurídico é utilizado enquanto o conjunto de áreas de atuação em que as ações do Serviço Social se articulam a ações de natureza jurídica, como o sistema judiciário, os sistemas penitenciário e prisional, o sistema de segurança, o ministério público, os sistemas de proteção e acolhimento e as organizações que executam medidas sócio educativas, conforme previstas no Estatuto da Criança e do Adolescente, dentre outros".

Intervenção profissional esta, negligenciada até pouco tempo com relação à produção bibliográfica sobre o campo, vem sendo cada vez mais alvo de interesse dos Assistentes Sociais. Uma hipótese levantada sobre isso é a do enxugamento do Estado Democrático de Direito com um retorno no trato da questão social como "caso de polícia”. Pequeno (2008) observa que o Sóciojurídico foi tema no X Congresso Brasileiro de Assistentes Sociais ocorrido no Rio de Janeiro em 2001, nesse mesmo evento foi lançada a edição ${ }^{\circ} 67$ da Revista Serviço Social e Sociedade, da Editora 
Cortez, que versou sobre "Temas Sócio-Jurídicos". A autora também destaca a fundação da Comissão Temática Sócio-Jurídica no Rio de Janeiro em 2002. Fávero (2006) ainda faz menção ao Encontro Nacional Sóciojurídico que ocorreu em Curitiba em 2004.

Em termos do Distrito Federal, a temática do Sóciojurídico tem sido uma das preocupações do Conselho Regional de Serviço Social - CRESS, $7^{\text {a }}$ região. Em comemoração a Semana do Assistente Social em 2009, foi dedicado um dia inteiro a temática. Organizado pela Comissão Temática Sócio-Jurídica do Distrito Federal, foram realizada duas mesas: primeiramente, a palestra expositiva ministrada pelo Prof. Dr. Vicente Faleiros intitulada "O papel das instituições sócio-jurídicas na garantia dos direitos humanos"; posteriormente, encaminhou-se para as experiências do Serviço Social no sistema Sócio-Jurídico, com a presença de Assistentes Sociais no Ministério Público do Distrito Federal e Território - MPDFT, do Tribunal de Justiça do Distrito Federal e Territórios - TJDFT, do Centro de Atendimento Juvenil Especializado CAJE e da Secretaria de Desenvolvimento Social e Transferência de Renda do Distrito Federal.

Retomando as características peculiares desse trabalho, no âmbito do Judiciário, verifica-se que as expressões da questão social na maioria das vezes se manifestam em razão da transgressão da lei pelo próprio Estado (CÓLMAN apud FÁVERO, 2004), que tendo sido omisso quanto à garantia universal dos direitos sociais, vai implicar numa responsabilização dos usuários pela garantia de seus próprios mínimos sociais por meio do trabalho independendo a sua condição laboral. Quando não se alcança esse objetivo, as únicas possibilidades do cidadão ser assistido pelo Estado é por meio da assistência social focalizada ou como réus em processos criminais (mais ainda essa última opção do que a primeira).

Enquanto espaço sócio-ocupacional, sabe-se que o Judiciário constitui-se como um dos primeiros contratantes do Serviço Social junto às Varas de Menores e Varas de Família. Fávero aponta que particularidades do fazer profissional nessa área passaram a vir a público diante da ampliação por demanda de atendimento e de profissionais devido às novas regulamentações que buscavam garantir mais direitos - vide a Constituição 
Federal de 1998, o Estatuto da Criança e do Adolescente, em 1990, entre outros - mas também ao crescimento do processo de judicialização da pobreza (ibidem).

Iamamoto (2004), ao analisar o Serviço Social enquanto profissão inserida em um campo tão contraditório como a Justiça, afirma que uma das possibilidades de atuação do assistente social é o assessoramento de magistrados. Nessa perspectiva, o constante aperfeiçoamento teórico-metodológico, técnico-operativo e ético-político fazse necessários para uma tradução mais apropriada da lógica de explicação do cotidiano na sociedade capitalista, aliado a um processo de pesquisa da realidade que permita decifrar situações particulares que se apresentem ao assistente social, não desvinculados dos processos socais da totalidade que as geram e modificam. Possibilitando, assim, a potencialização dos níveis de assessoria, planejamento, negociação, pesquisa e ação direta, que permitam aos sujeitos participantes um meio de se efetivarem também nas decisões que lhes façam jus, na defesa de seus direitos e no acesso a meio de exercê-los. Partindo do princípio que a atuação do Serviço Social na Vara de Execuções Penais por meio da Seção Psicossocial segue os moldes descritos acima, passa-se a uma análise dos processos de trabalho do assistente social nesse espaço sócio-ocupacional.

\subsection{Processos De Trabalho Na Seção Psicossocial Da Vara De Execuções Penais}

A criação da Seção Psicossocial da Vara de Execuções Penais - SEVEP data de 17 de janeiro de 1987, criada por força da portaria interna ${ }^{\circ} 3$ com o nome de Seção da Vara de Execuções Criminais (SEVEC). Segundo esta portaria compete à esta Seção: I) prestar assessoria ao Juiz da VEC nos assuntos psicossocias relativos à execução de penas; II) fornecer subsídios para as decisões judiciais, especialmente no que se refere aos aspectos subjetivos; III) monitorar o cumprimento dos benefícios concedidos aos sentenciados do Distrito Federal; IV) Articular-se com outros órgãos no sentido de promover o retorno dos sentenciados ao convívio social.

No que tange a missão institucional, o documento apresenta que as trabalhadoras da Seção devem buscar atender às demandas judiciais relativas à execução penal, no que 
diz respeito aos seus aspectos psicossocias, garantindo, assim, o exercício efetivo da cidadania dos seus usuários. E para tal, as profissionais devem aprimorar os conhecimentos técnicos inerentes aos aspectos psicossociais, buscando a melhoria do atendimento das necessidades e das expectativas dos usuários, assim como a qualidade dos estudos psicossocais; promover a articulação com instituições públicas e privadas, objetivando a constituição de uma rede social de apoio e atendimento aos usuários; além de buscar o envolvimento do grupo familiar no processo de retorno gradativo ao convívio social.

Sobre os princípios que norteiam a ação das profissionais, tem-se: i) a multidisciplinariedade; ii) o trabalho em grupo; iii) o exercício da cidadania e diversidade; iv) a articulação/fortalecimento de redes; v) o respeito à dignidade e integridade; vi) a promoção do bem-estar social; e vii) a escuta qualificada e acolhimento.

A Seção Psicossocial da Vara de Execuções Penais - SEVEP conta, atualmente, com quinze profissionais, sendo cinco Assistentes Sociais, nove Psicólogas e uma Socióloga além da presença de três estagiárias - duas na área da Psicologia e uma do Serviço Social. O último concurso para preenchimento de vagas nessas duas áreas, Serviço Social e Psicologia, ocorrido em 2008, permitiu a lotação de novas técnicas na Seção. Desde as primeiras efetivações, foram oito profissionais inseridas no quadro de pessoal, ao mesmo tempo, três profissionais - e uma quarta, no momento - que pediram transferência para outras unidades do TJDFT.

Até o ano de 2008, a SEVEP passou por várias disposições da repartição de seus trabalhos: inicialmente, todos os técnicos da Seção executavam atividades de acompanhamento independente da especificação do caso, se de sentenciado imputável ou inimputável. Em seguida, procedeu-se a divisão interna da equipe em duas - Equipe de Acompanhamento de Medida de Segurança e Equipe de Estudos e Acompanhamento de Presos e Egressos (EAPE) - sendo que a cada certo período de tempo realizava-se um rodízio dos técnicos para que todos pudessem conhecer todas as atuações. Nos últimos anos, a divisão da equipe persistiu, porém, sem rodízio entre técnicos, sendo executada uma ação de troca de equipes somente se fosse o interesse do(a) técnico(a). Ao final de 2008, tentou-se proceder a uma nova configuração dos trabalhos parecida 
com a segunda da fase da Seção, desta vez, as profissionais que tivessem interesse poderiam acompanhar casos da outra equipe. Até o presente momento, ainda não há avaliações claras sobre essa nova perspectiva bem como a adesão ao novo projeto foi de parte das profissionais, sendo que suas intervenções ainda se dão em caráter experimentativo. Uma grande mudança a partir de 2000 foi a configuração da equipe que atua junto ao Trabalho Externo como permanente, ou seja, devido ao grande volume de processo de avaliação de proposta, optou-se por designar pelo menos uma técnica específica para a área. No último ano também se procedeu a mudanças na chamada EAPE - Equipe de Estudos e Acompanhamento a Presos e Egressos, pois devido a extinção do Programa de Livramento Condicional, que passa a ser executado pela Vara de Execuções de Penas e Medidas Alternativas - VEPEMA, a equipe restringe-se ao atendimento de sentenciados em penas restritiva de liberdade especificamente em Regime Fechado e Semi-Aberto.

A demanda da Seção Psicossocial configura-se como interna já que o encaminhamento do processo penal é feito por meio de sentença judicial (SOUZA, 2004). Os despachos que o Juiz da Execução, normalmente, expede requerem visita domiciliar para fins de concessão de benefício de Saídas Temporárias ${ }^{17}$ e, em se tratando do benefício de Trabalho Externo ${ }^{18}$, o despacho solicita que seja convocado o empregador para avaliação da proposta de trabalho anexada ao processo. A cada dia chegam novos processos com deferimentos do Juiz que são, então, encaminhado à Chefe da Seção que averiguará o despacho do Juiz, isto é, se aquele caso trata-se de acompanhamento da Medida de Segurança ${ }^{19}$, ou de estudo social para concessão de benefícios; e, posteriormente, procederá a partilha destes entre as técnicas.

\footnotetext{
${ }^{17}$ As Saídas Temporárias são um benefício do Regime Semi-Aberto concedido pelo Juiz da Execução àquele que, até a data da saída, tenha cumprido um sexto da pena total se for primário, ou um quarto se for reincidente. Outro quesito analisado é a boa conduta carcerária, averiguada por meio do Relatório Carcerário (Lei de Execuções Penais, 1984).

${ }^{18} \mathrm{O}$ benefício de Trabalho Externo não se configura como limitado ao Regime Semi-Aberto, podendo também ser atribuído ao apenado em Regime Fechado, sendo requisitado apenas o cumprimento de 1/6 da pena. Trata-se de dever social e condição de dignidade humana, que tem por finalidade a ação educativa e produtiva (Lei de Execuções Penais, 1984).

19 A medida de segurança é atribuída ao agente considerado inimputável - aquele que por anomalia psíquica ou retardo mental não pode responder por si judicialmente. O juiz determinará sua internação ou seu tratamento ambulatorial, quando o fato previsto como crime for punível com detenção. A internação,
} 
Em seguida, no caso do atendimento ao benefício de Saídas Temporárias, após a partilha entre as técnicas dos processos correspondentes, é realizado o estudo do processo que visa conhecer o caso apontando as páginas onde as principais informações estão descritas, por exemplo: encaminhamento do Juiz para a SEVEP; sentença de progressão para o Regime Semi-Aberto; relatório carcerário, se consta alguma falta disciplinar e eventuais atividades laborais ou estudos realizados intramuros; algum relatório de atendimento pela equipe multiprofissional do presídio; relatório do Instituo Médico Legal - IML; além de informações sobre o delito cometido. Em seguida, por meio da intranet, busca-se os dados do sentenciado que constam no presídio para se averiguar o endereço, telefone, visitantes do interno. O ópera, nome dado a esse documento, traz as informações necessárias para a convocação de familiares e/ou amigos para formalização junto a VEP da residência em que se encontrará o sentenciado em caso de concessão de Saídas Temporárias.

A convocação dos familiares e/ou amigos se dá por meio de telegrama informando da necessidade de comparecimento à SEVEP para tratar do assunto relativo à concessão de Saídas Temporárias. Anteriormente, os telegramas enviados já informavam a cerca da data do atendimento ou reunião proposto, porém, atualmente, essa correspondência pede que o receptor entre em contato com a SEVEP para agendamento de atendimento e confirmação da presença. $\mathrm{O}$ atendimento segue, então, duas fases: a primeira de entrevista individual visa buscar as informações mais descritivas do entrevistado além de um pequeno levantamento da história de vida do sentenciado e da convivência entre ele e o familiar presente. Posteriormente, acontece um momento em grupo com todos os atendidos naquele dia - seja por Assistente Social ou por Psicóloga - que busca orientar os presentes a cerca das regras do benefício, além de promover a socialização de experiência, se assim desejarem os participantes, e, principalmente, promover um processo de desculpabilização dos familiares, ou seja, fazê-los refletir que não são responsáveis pelo delito cometido pelo sentenciado, mas que, ao mesmo tempo, são peças-chave no apoio ao retorno do convívio social dele.

ou tratamento ambulatorial, será por tempo indeterminado, perdurando enquanto não for averiguada, mediante perícia médica, a cessação de periculosidade. O prazo mínimo deverá ser de 1 (um) a 3 (três) anos (CÓDIGO PENAL, 1940). 
Terminada a fase de atendimento, elabora-se, por fim, o relatório social com as informações coletadas. Ao longo dos anos, esse instrumental vem sofrendo alterações de sua estrutura e conteúdo, porém basicamente segue a ordem de colocação: cabeçalho com o nome do sentenciado, filiação, endereço e telefone; um primeiro parágrafo sintético em que é apresentado os procedimentos realizados bem como é registrado a presença do familiar e/ou amigo; em seguida, informa-se sobre a finalidade desse atendimento; posteriormente, encaminha-se para uma pequena análise do tema central debatido no grupo; então, apresenta-se a história de vida do sentenciado na percepção do entrevistado; segue para a configuração do lar onde residirá o apenado; e, finalmente, procede-se a encaminhamentos ou conclusões do atendimento realizado.

O relatório tendo sido concluído, é encaminhado à Chefe da Seção para fins de correção de erros e reformulação dos dados escritos. Após seu parecer, o processo retorna à técnica para que faça as devidas correções e dê o andamento final ao caso. Feitas as correções, imprime-se duas cópias - uma que irá com o processo e outra que restará na Seção em forma de arquivo. O processo é então encaminhado para o cartório, não se obtendo informações sobre o seu andamento posterior e nem sobre a sentença julgada. Como se observará mais a frente, esse é o grande dilema da atuação na SEVEP, por estar inserida em uma instituição lógica formal, o Judiciário não é permeável de fluidez em suas decisões, a divisão alienada do trabalho faz com que o retorno do serviço prestado fique num limbo difuso.

Sobre a atuação profissional junto ao benefício de Trabalho Externo, os procedimentos realizados seguem uma lógica um tanto diferente da outra equipe. Visto a alta rotatividade de processos, as atividades realizadas seguem a ótica da celeridade. $\mathrm{O}$ grande volume de processos com propostas de trabalho necessita que o atendimento seja eficiente, na coleta de dados sobre as condições de trabalho, e efetivo, ao informar sobre as regras do benefício, elucidando todas as dúvidas.

Até o momento em que o processo é repassado para a técnica responsável, este tramita de maneira normal apresentada acima, após é feito uma coleta de informações acerca do signatário da proposta de emprego, procedendo, já em seguida, à sua convocação já com a data marcada para o atendimento em grupo de empregadores - as reuniões ocorrem sempre às quartas-feiras às $14 \mathrm{~h}$. O primeiro momento da reunião é a 
triagem de documentação e preenchimento do Termo de Compromisso do Empregador. Posteriormente é transmitida informações quanto as regras do benefício e a fiscalização realizada pelos órgãos responsáveis pela execução penal. Havendo terminado a reunião, elabora-se relatório, que seguirá os mesmo tramites já mencionado acima até ser encaminhado ao cartório.

Segundo Souza (2004), o papel do assistente social na Seção Psicossocial é, partindo da demanda institucional, utilizar seus conhecimentos teórico-metodológicos para compreender e explicar as múltiplas expressões e determinações da questão social que se expressam nos conflitos e dissídios judicializados e, dialeticamente, intervir utilizando conhecimentos técnico-operativos inerentes, mas não privativos do Serviço Social. 


\section{UM OLHAR MAIS PROFUNDO SOBRE O OBJETO DE TRABALHO: A REINCIDÊNCIA CRIMINAL E A EVASÃO}

Retomando neste item o problema de pesquisa: analisar em que medida a atuação do Assistente Social contribui para os reduzidos índices de foragidos e índices de reincidência no Distrito Federal, observa-se que as variáveis que o compõe são "Serviço Social", "foragidos" e "reincidência". Neste capítulo, objetiva-se uma análise mais aprofundada, nos termos da sociologia jurídica, dessas duas últimas variáveis, traduzidos como reincidência criminal e fuga, já que o tratamento do Serviço Social no espaço sócio-ocupacional sócio-jurídico fora abordado anteriormente. Inicialmente, propõe-se um resgate histórico dos dois termos, demonstra como eles foram construídos ao longo do tempo e que se consolidaram como atenuantes agravantes das penas.

A partir do discurso jurídico-penal do Iluminismo, Teixeira (2007) aponta que quando do surgimento do crime como descrição legal nesse período, a reincidência ainda não era fator agravante da pena, apesar de se considerar o criminoso aquele que "violou livremente (capacidade, conhecimento e vontade) o contrato social" (p.89). Em citação de Zaffaroni apud Teixeira sobre a questão, faz-se patente a noção de que, àquela época e após o cumprimento da pena para a conduta tipificada como crime, o indivíduo não deveria ser considerado infame e desonrado pelos atos cometidos no passado, os quais já haviam sido totalmente expurgados em decorrência da pena sofrida.

Após o alijamento do pensamento iluminista, o Positivismo a partir do retorno ao modelo inquisitorial de constatação do crime, institui a reincidência, assim como os antecedentes criminais e as análises de personalidade com o objetivo de averiguar as "tendências criminosas" do sujeito. O autor expõe que, a partir desse momento, a justiça penal intenta o combate à criminalidade e, não somente, o julgamento dos ilícitos cometidos, porquanto que a diferenciação entre réu primário e reincidente se torna importante: "para a avaliação da periculosidade do delinqüente, é necessário ter em conta o seu grau, a sua provável duração e a sua tendência” (FERRI apud TEIXEIRRA, 2007:90)

Com a superação do Positivismo como doutrina de compreensão da sociedade, pelo menos em termos gerais visto que a instituição da Justiça ainda carrega bastante 
dessa carga positivista em seus julgamentos, a reação social vai denunciar os perigos dessa ideologia estigmatizante, na medida em que averiguações de antecedentes e reincidência reforçam as percepções sobre a qualidade do indivíduo e criam uma expectativa que, se não for cumprida, reforça ainda mais a condição de "criminoso" do sujeito (ibidem).

Nesse momento, o autor propõe uma pequena diferenciação entre os conceitos de antecedentes e reincidência. Os chamados "maus antecedentes" possuem uma conotação divergente da reincidência, aqueles não são extintos com o passar do tempo, sendo, portanto, perpétuos. A sua representatividade para o julgador é demonstrar os maus feitos pelo sujeito, aliás esse é o grande debate a cerca desse conceito, pois não se toma os "bons antecedentes" do indivíduo, mas somente os fatos que de alguma forma implicaram em registro penal (ibidem).

Segundo o Código Penal brasileiro (1940) em seu art. 63, "verifica-se a reincidência quando o agente comete novo crime, depois de transitar em julgado a sentença que, no País ou no estrangeiro, o tenha condenado por crime anterior". Observa-se que a definição da reincidência não está mencionada neste artigo, o que é traduzido são as condições para a sua verificação. O legislador ainda deixa claro que, para configurar-se como reincidência, existem ainda dois outros mecanismos no art. 64 do mesmo código que devem ser levados em conta: a) o lapso temporal entre a extinção ou cumprimento da pena do primeiro delito e a execução do crime ulterior deve ser inferior a cinco anos; e b) os crimes militares próprios e políticos não geram reincidência.

Em citação de Damásio, Machado apresenta algumas situações de verificação da aplicação da reincidência:

"a) o sujeito comete um crime no dia 10 de janeiro, indo a praticar outro no dia 12 de janeiro: não é reincidente (trata-se de reiteração criminal);

b) o sujeito comete um crime; no transcorrer da ação penal, vem a cometer outro crime: não é reincidente;

c) o sujeito pratica um crime, sendo condenado; recorre; enquanto os autos se encontram no Tribunal, vem a cometer outro: não é considerado reincidente;

d) o sujeito, condenado irrecorrivelmente pela prática de um crime, dias após pratica novo delito; é considerado reincidente" (DAMÁSIO apud MACHADO, s.n.t p.3). 
Machado (ibidem) faz diferenciações entre as espécies de reincidência existentes, distinguido duas classificações distintas: quanto ao tempo - ficta ou real - e quanto a natureza ou espécie do crime - genérica e específica.. Para efeitos da reincidência ficta, considera-se o delito cometido após o trânsito e julgado do litígio anterior, bem como a reincidência real parte do principio que esta somente se concretiza se o crime ulterior tenha se efetivado após o transito e julgado do anterior e o cumprimento da respectiva pena aplicada.

As discussões mais acalentadas sobre as espécies de reincidência centralizam-se no que tange a natureza ou espécie do fato criminoso. A reincidência genérica ou simples considera que para a sua efetivação basta que o agente cometa outro crime depois do delito anterior se tornar irrecorrível, ao passo que a reincidência especifica é atribuída ao fato concretizado da mesma natureza que o delito transitado e julgado anteriormente. As divergências sobre esse tema focam sobre em qual perspectiva de analise se centrar: na da natureza - então a reincidência se configura quando possuem algum nexo, por exemplo, furto e roubo? Ou na da espécie - então a reincidência se daria somente quando cometidos crimes do mesmo artigo penal?

O nosso Código Penal Brasileiro atribui à reincidência as características de ser genérica e ficta, isto é, considera-se reincidente o individuo que cometeu crime ulterior, de qualquer espécie ou natureza, após o transito e julgado no delito anteriormente concretizado.

Para além dessa problemática conceitual, verifica-se que a reincidência como instituto penal vem sendo criticada quanto a sua utilização para agravamento de pena posterior. Dos questionamentos mais à esquerda, observa-se que o uso da reincidência como agravante se configura na retomada de antigas práticas judiciais de (re)punição do individuo por algo que ele já fora julgado. A reincidência pode agravar a pena privativa de liberdade; impedir a substituição da pena privativa de liberdade por uma restritiva de direitos, se especifica em crime doloso, impedir a substituição da pena privativa de liberdade pela multa; aumentar o tempo de cumprimento da pena para obtenção do livramento condicional; revogar livramento condicional; impedir a prestação de fiança; e impossibilitar a apelação em liberdade. Como diria Cirino dos Santos sendo citado por Teixeira (2007): 
E a questão é esta: se a pena criminal não tem eficácia preventiva mas, ao contrário, possui eficácia invertida pela ação criminógena exercida -, então a reincidência criminal não pode constituir circunstância agravante (p. 93).

A contra crítica reacionária a essa crítica é apresentada por meio do outro artigo aqui utilizado. Machado explicitamente defende a necessidade do agravamento penal quando se tratar de um réu reincidente. E para isso, retoma o jurista Aníbal Bruno que opina

Hoje se pode justificar a exacerbação da pena, ao segundo crime, pela maior culpabilidade do agente, pela maior reprovabilidade que sobre ele recai em razão de sua vontade rebelde particularmente intensa $e$ persistente, que resistiu à ação inibidora da ameaça da sanção penal e mesmo da advertência pessoal, mais severa, da condenação infligida, que para um homem normalmente ajustável à ordem do Direito, isto é, de temperamento e vontade menos decisivamente adversos aos impedimentos da norma, seria estímulo suficiente para afastá-lo da prática de novo crime (BRUNO apud MACHADO, s.n.t. p. 2) ${ }^{20}$.

Porquanto toda a sua crítica se baseia numa simples analise positivista da norma jurídica sem atentar para a totalidade do próprio sistema penitenciário. $\mathrm{O}$ autor aponta que o reincidente é o ser que se utiliza de "[...] uma obstinação, uma teimosia na prática ou abstenção de certa conduta genericamente determinada" (ibidem, p. 2).

Para além dessa discussão sobre o termo reincidência, é preciso levar em consideração que o seu índice é um mecanismo utilizado por muitos autores para fins de comparação entre presídios, estados ou países. Por isso faz-se necessário salientar algumas dados existentes ou não existentes sobre reincidência criminal no Distrito Federal e no Brasil.

Como salienta o Relatório da Comissão Parlamentar de Inquérito do Sistema Carcerário $^{21}$, dados apresentados pelo órgão responsável pela execução da Política

\footnotetext{
${ }^{20}$ Grifo meu.

${ }^{21}$ Comissão Parlamentar de Inquérito, criada em agosto de 2007 e encerrada em junho de 2008, objetivou investigar a realidade do Sistema Carcerário brasileiro, com destaque para: a) a superlotação dos presídios, b) os custos sociais e econômicos desses estabelecimentos, c) a permanência de encarcerados que já cumpriram pena, d) a violência dentro das instituições do sistema carcerário, e) a corrupção, f) o crime organizado e suas ramificações nos presídios. Buscou-se a partir das diligências feitas em presídios do país, soluções para o efetivo cumprimento da Lei de Execuções Penais. Os membros da comissão foram Neucimar Fraga, Jusmari Oliveira, Cida Diogo, Paulo Rubens, Felipe Bornier, Iriny Lopes, Luis Carlos Busato, Talmir Rodrigues, Arnaldo Faria de Sá, William Woo, Alexandre Silveira, Pinto Itamaraty, Jorginho Maluly, Airton Xerez, João Campos, Ernani Amorim, Janete Capibaribe, Virgílio Guimarães, Valtenir Luiz Pereira, Marcelo Itagiba, Padre Couto, Padre Linhares, Luciana Costa, Maria do
} 
Penitenciária Nacional, qual seja o Departamento Penitenciário Nacional - DEPEN não permitem que se afirme, com certeza, o percentual de recidiva no sistema carcerário brasileiro. Observou-se que inexistem estatísticas oficiais sobre a taxa de reincidência no país.

As informações aqui prestadas, então, demonstram apenas o quantitativo de reclusos reincidentes e a tentativa de formulação de uma taxa de reincidência tem por base essa população. Todos os dados apresentados seguem o demonstrativo estatístico do INFOPEN - Sistema de Informações Penitenciárias ${ }^{22}$, um programa de coleta de dados, via internet, do DEPEN que é atualizado em média a cada seis meses.

No que tange ao Brasil, a partir de uma população penitenciária de 440.013 distribuídos entre presos provisórios, em Regime Fechado, em Regime Semi-Aberto, em Regime Aberto, em Medida de Segurança no modo Internação, em Medida de Segurança em modo de Tratamento Ambulatorial além do efetivo preso na polícia, contabilizaram-se, até junho de 2008, 74.736 internos reincidentes, o que equivale a $17 \%$ da dessa população. Vale lembrar que somente $87 \%$ dos estabelecimentos responderam à chamada do DEPEN nesse quesito, o que equivale a 958 unidades prisionais.

Segundo ainda este documento, o Distrito Federal possuía a época, uma soma de 7.812 reclusos sendo que desses 421 eram reincidentes, perfazendo um índice de 5,4\%. Nesse ano, esse percentual representou ou quinto menor coeficiente, sendo excluídos dessa análise os estados de Ceará e Rio Grande do Sul que não preencheram completamente os dados, tendo afirmado que não possuíam presos reincidentes em suas penitenciárias $^{23}$.

Partindo para o item seguinte da discussão desse capítulo, intenta-se abarcar o tema da fuga com base em artigos que tragam hipóteses sobre as causas mais plausíveis

Carmo Lara, Bruno Rodrigues, Carlos Sampaio, Raul Julgmann, Pompeu de Matos, Francisco Tenório, Paulo Abi-Ackel e Pedro Eugênio. O Relatório da Comissão está disponível no sítio da Câmara dos Deputados no link das "CPIs encerradas".

${ }^{22}$ O INFOPEN foi criado em 16 de setembro de 2004 com o objetivo de "oferecer à União informações confiáveis, subsidiárias à administração do Sistema Penitenciário Nacional e para o direcionamento de políticas públicas neste mesmo âmbito" (MINISTÉRIO DA JUSTIÇA 2006)

${ }^{23}$ No estado do Ceará, $83 \%$ dos presídios responderam o item, o que segundo o DEPEN equivalia a 120 unidades. No Rio Grande do Sul somente 5\% dos estabelecimentos prisionais acessaram esse item da tabela o que corresponde a 5 unidades. 
para sua efetivação. Segundo a Subsecretaria do Sistema Penitenciário - SESIPE, o Distrito Federal possui, hoje, 849 sentenciados foragidos. Salla, ao discorrer sobre as rebeliões nas prisões brasileiras, indica que, usualmente, os motins têm por função chamar a atenção da opinião pública para as condições de vida no interior dos presídios, que incluem:

"a deterioração das condições físicas dos locais de encarceramento, a superlotação, a falta de condições de higiene, a inexistência de serviços de assistência a saúde, a falta de assistência jurídica, a corrupção e a incompetência administrativa, além da Constancia na prática de tortura" (SALLA, 2001:20).

Fazendo um paralelo para as iniciativas de fuga do sistema penitenciário, a violação dos direitos humanos dos reclusos apontada pelos exemplos acima, configurase motivo suficiente para tal iniciativa.

Segundo o Relatório da CPI, o Distrito Federal possui um déficit de 1.917 vagas e a superlotação chega a $21 \%$. Em termos de assistências garantidas na Lei de Execuções Penais - material; à saúde; jurídica; educacional; social; religiosa - tanto quanto estarrecedor é a situação. Os presídios não contam com equipes de saúde próprias e fixas, pois quem as gerencia é a Secretaria de Estado de Saúde do Distrito Federal - SES por meio de contrato com profissionais da área que duram em média um ano. Após esse período, as equipes são substituídas, não dando, assim, continuidade ao trabalho realizado pelas equipes anteriores. Somente para exemplificar, o Sistema Prisional inteiro contava com apenas um psiquiatra com carga horária de $20 \mathrm{~h}^{24}$.

Sobre a assistência jurídica, o DF conta com quatro Defensores Públicos para a gama de quase 8.000 presos. A educação também padece de atenção, em dezembro 2008, segundo o Relatório de Atividades do GDF, somente 813 presos estudavam o que representa um pouco mais do que $10 \%$ de toda a massa carcerária. Em termos de trabalho, o Relatório mencionado informa que no mesmo período 1.558 sentenciados trabalhavam e somente 82 exerciam alguma atividade laboral e também estudavam.

\footnotetext{
${ }^{24}$ Informações constantes no Relatório de Atividades do Governo do Distrito Federal de 2008.
} 
Retomando a questão da fuga, observa-se, porém que apesar do tratamento que sofrem os apenados, o Distrito Federal tem um dos menores índices de fuga, sendo que nos últimos dados apresentados pelo DEPEN, não foi registrado qualquer fuga. Contudo a tomada desses dados deve ser analisada com certa frieza, pois em termos de Saídas Especiais, há sempre alguma fuga empenhada.

Aprofundando ainda mais no tema, é preciso salientar que o objeto desse estudo restringe-se a fuga decorrente de Saídas Especiais, e, portanto entender o processo que possibilita o sentenciado a ter seis saídas no ano em datas comemorativas para visitar a família é importante.

Segundo as portarias de regulação das Saídas Especiais, estas se inserem no âmbito das denominadas Saídas Temporárias, sendo concedidas a sentenciados que estejam cumprindo pena em Regime Semi-Aberto e que tenham bom comportamento, tendo por objetivo da saída a visitação à família. A última portaria da Vara de Execuções Penais lançada para regulação das Saídas Especiais do Dia das Mães afirma que além das condicionalidades acima informadas o sentenciado, para fazer jus a esse benefício, deve também ter a autorização para saídas temporárias e benefício de trabalho externo, efetivamente, implementado, ou trabalho externo deferido, tendo usufruído, ao menos, de uma das saídas especiais nos últimos 12 meses.

Com base nos ensaios de Wacquant (2001), essa restrição do benefício pode ser entendida na ótica do incremento do Estado Penal que entre as suas artimanhas se utiliza do aumento de barreiras para a conquista de benefícios como forma de exclusão do preso. Uma segunda análise, retomando Goffman (1997), diz respeito aos mecanismos disciplinares característicos da instituição total que promove a recompensa como forma segregação dos internos.

O benefício ainda inclui algumas regras que devem ser cumpridas com rigor, numa perspectiva clara de moldagem do comportamento a ser seguido. As condições de cumprimento são

1) não praticar fato definido como crime; 2) não praticar falta grave; 3 ) recolher-se à sua residência até às $18 \mathrm{~h}$, podendo, durante o dia, transitar, sem escolta, no território do Distrito Federal, para o cumprimento das atividades que concorram para seu retorno ao convívio social; 4) ter comportamento exemplar; 5) manter bom relacionamento com a família; 6) não ingerir bebidas alcoólicas, não fazer uso ilícito de entorpecentes e nem frequientar prostíbulos, bares ou botequins; 7) não 
andar na companhia de outros internos ou ex-internos, de quaisquer espécies; 8) não se ausentar do Distrito Federal, exceto os que residem nas cidades que formam a região do entorno; 9) fornecer informações aos órgãos ou entidades encarregados da fiscalização das presentes condições, caso solicitadas; 10) portar documentos de identificação; 11) retornar ao estabelecimento prisional no dia e hora determinados. Encaminhe-se cópia desta Portaria à SESIPE/DF. Publique-se e cumpra-se (PORTARIA No 07, de 29 de abril de 2009).

Posto isso e em observação dos dados a cerca das fugas nas últimas seis Saídas Especiais, quais sejam: Ano Novo, Páscoa, Dia das Mães, Dia dos Pais, Dia das Crianças e Natal, averiguou-se que o Distrito Federal possui um dos menores índices de foragidos do país, o número de evadidos das penitenciárias representaram um coeficiente que girou em torno de $0,3 \%$ e $1,75 \%$. A média nacional, segundo informações prestadas pelo diretor adjunto da subsecretaria do Sistema Penintenciário do DF, Sr. Adiel Teófilo, ao Jornal de Brasília, está em torno de $10 \%$. 


\section{ANÁLISE DE DADOS}

Partindo do problema de pesquisa, qual seja: analisar em que medida a atuação do Assistente Social contribui para os reduzidos índices de foragidos e índices de reincidência no Distrito Federal, a análise de dados é composta por duas partes: a primeira trata da configuração dos usuários da Seção Psicossocial da Vara de Execuções Penais e a segunda a análise das observações e entrevistas realizadas com as assistentes sociais e as famílias dos sentenciados.

\section{Características Dos Usuários Da SEVEP}

Com o objetivo de averiguar as características dos usuários do Serviço Social na Seção Psicossocial da Vara de Execuções Penais - SEVEP foi feito um levantamento de 90 relatórios dos anos de 2006, 2007 e 2008, perpassando um total de 30 relatórios analisados por cada exercício. Buscou-se com essa ação interpelar as principais características dessa população: por parte dos familiares, identificar o/a sujeito/a que respondeu à solicitação do telegrama encaminhado; e por parte do sentenciado/a, analisar dados de perfil - nível de escolaridade, profissão, saúde - e a sua rede de apoio familiar - quantitativo de irmãos, presença de genitores, naturalidade da família, quantidade de filhos e estado civil.

Os relatórios analisados foram aleatoriamente escolhidos nos anos propostos acima. A escolha desse triênio seguiu a intenção da construção de um painel analítico que pudesse conduzir as investigações posteriores e com isso identificar uma possível tendência dessa população. Nesse período, os estudos sociais que se materializaram em relatórios foram produzidos por quatro Assistentes Sociais, sendo que duas dessas não mais figuram no quadro de pessoal da Seção. Partindo para uma análise do instrumental, o Conselho Federal de Serviço Social informa que o relatório social

\footnotetext{
“constitui um documento específico elaborado por assistentes sociais, que se traduz na apresentação descritiva e interpretativa de uma situação ou expressão da questão social, enquanto objeto da intervenção desse profissional, no seu cotidiano laborativo". (CFESS, 2004:44)
} 
O instrumental como elemento essencial da mediação do trabalho da Assistente Social com o Juiz da Execução tem duas finalidades principais na SEVEP, a saber: realização de um estudo social da família ou grupo familiar que irá receber o sentenciado para fins de benefício de Saídas Temporárias do Regime Semi-Aberto (um total de 80 relatórios); ou relato do acompanhamento por parte do sentenciado das reuniões de Livramento Condicional - benefício do Regime Aberto (8 relatórios). Somente dois casos, que não tinham esses dois benefícios como objetivo do atendimento, foram observados: um por conta de demanda espontânea da genitora do sentenciado que requisitava tratamento médico para seu filho por conta do uso de drogas; e outro relatório que tinha como fim o acompanhamento da efetivação de atendimento psicológico que deveria ser realizado pelo sentenciado na unidade prisional. Uma última ressalva antes de se proceder a análise, dos 90 relatórios analisados somente 4 são de mulheres sentenciadas e outros 86 documentos referem-se a homens sentenciados.

Iniciando a observação dos dados coletados, é característica a presença feminina maciça nas convocações para grupo de familiares ou atendimento individuais que objetivam o tratamento do benefício de Saídas Temporárias. Dos 80 relatórios que tinham por finalidade debater sobre esse benefício, 69 ou 86,25\% deles relatavam a presença de alguma mulher no atendimento, podendo ela ter sido qualificada como genitora, irmã, esposa, ex-esposa, madrasta, cunhada, tia, amiga, companheira, namorada, filha, prima, ou cunhada.

\begin{tabular}{|c|c|c|c|c|c|c|c|c|c|c|}
\hline \multicolumn{11}{|c|}{ Presença de Mulheres em atendimentos da SEVEP* } \\
\hline Genitora & Irmã & $\begin{array}{l}\text { Esposa / } \\
\text { Ex-Esposa / } \\
\text { Companheira } \\
\text { / Namorada }\end{array}$ & $\begin{array}{l}\text { Sogra/ } \\
\text { Ex-Sogra }\end{array}$ & Tia & Prima & Cunhada & Amiga & Sobrinha & Madrasta & Filha \\
\hline 36 & 14 & 17 & 2 & 4 & 4 & 1 & 5 & 1 & 1 & 1 \\
\hline
\end{tabular}

*Em alguns atendimentos, mais de um familiar esteve presente, motivo pelo qual a soma dessas participações supera o número de relatórios que identificam a presença de mulheres.

Esses dados reforçam a ideário capitalista que apresenta a mulher na função de reprodutora das relações sociais, enquanto homens seriam responsáveis pela produção. Marx já dizia que a história da sociedade capitalista é a história dos homens, ou a 
história da forma como esses subjugaram, a um segundo plano, mulheres e crianças, atribuindo-lhes o status de propriedade privada: "o burguês vê na própria esposa um simples instrumento de produção" (MARX, 2005:63)

Engels, em A Origem da Família, da Propriedade Privada e do Estado (s.d.) aborda a divisão do trabalho familiar nas sociedades primitivas que já apresentava as mulheres no trato do espaço doméstico e os homens como pertencentes ao mundo da guerra, caça e responsáveis pela sustentação da família, apesar disso, essa divisão não possuía uma diferenciação na sua importância. Concebia-se as funções igualmente necessárias para o desenvolvimento da tribo. O autor analisa que com o surgimento da propriedade privada que essas relações são modificadas, mulheres e crianças passam por um processo de coisificação de seus corpos por não estarem inseridos no processo produtivo.

Portanto, a tabela apresentada representa somente essa persistência da função de cuidar que às mulheres foi relegado. Fazendo um paralelo com o documentário Do Lado de Fora de Paula Zanettini e Monica Marques (2005) ${ }^{25}$ produzido no Rio de Janeiro, em que uma gama de mais de 50.000 mulheres visitam amigos ou parentes nas penitenciárias do estado, é notável também no Distrito Federal a representatividade feminina nas visitas. A entrevistada B dessa pesquisa ao ser questionada de como se dava o processo de visita a seu familiar, fez apontamentos acerca do estigma que carregam, expressões como "mulher de bandido", "mãe de ladrão" são constantes no seu dia a dia. Para além disso, a máxima do "se parente de bandido, também é bandido" faz com que os trâmites para ter um tempo com o seu familiar sejam ainda mais doloroso.

Analisando mais profundamente o perfil de constituição da família desses sentenciados, nota-se que a média da prole a qual fazem parte é de 5,8 filhos - esse

\footnotetext{
${ }^{25}$ Do Lado de Fora registra a rotina de seis mulheres que visitam parentes na Penitenciária de Bangu, no Rio de Janeiro. A proposta do documentário foi trazer à tona as longas horas de espera, filas, revistas íntimas que essa mulheres passam para ter algum tempo com os seus familiares. O ritual da visita começa na véspera: preparar a comida, arrumar os produtos de higiene, ensacar cigarros. Tudo obrigatoriamente de acordo com as regras prisionais. Algumas chegam a dormir em frente aos presídios para garantir os primeiros lugares da fila. Mas a hora mais dolorosa é a volta pra casa (DOCTV, acessado em 01 de julho).
} 
número equipara-se à taxa de fecundidade em 1970 no Brasil26. Muito desses filhos foram criados pelas avós, visto o falecimento de um ou dos dois genitores ou mesmo a necessidade de inserção no mercado de trabalho da figura materna para a complementação da renda familiar. O processo caracterizado por alguns autores como feminização do trabalho nada mais é que o ferimento da própria lei geral do trabalho que prevê o assalariamento como o valor pago pelo aluguel da força de trabalho do operário e que deveria ser suficiente para garantir não somente a sua produção enquanto ser social, mas também a sua reprodução, ou seja, atender também às necessidades básicas de sua família.

Observa-se também, que esse quantitativo de filhos cairá significativamente quando o sentenciado(a) é o(a) progenitor(a). A taxa de fecundidade averiguada fica em torno de 2,1, inferior ao número apresentado no último censo do Instituto Brasileiro de Geografia e Estatística - IBGE de 2000, em que a média nacional foi de 2,3 e a do Centro-Oeste de 2,2. Esse número levanta a hipótese de reforço da característica dessa instituição total que é a prisão, isto é, a sua função de disciplinadora dos corpos, além de, numa perspectiva utilitarista e etiológica, impedir a reprodução de descendentes com característica criminosas.

Partindo para a análise dos dados referentes aos sentenciados, três características definem bem essa população: baixa escolaridade; profissões de baixo nível hierárquico e assalariamento, além de graves casos de alcoolemia e/ou drogadição. Aspectos esses referendados pelas Assistentes Sociais entrevistadas. Segundo suas percepções, uma população desassistida pelo Estado que sem acesso aos mínimos para sua constituição como cidadão, quais sejam educação, trabalho e saúde fazem com que venham cair nas malhas da Justiça como o "ponto mais fraco de uma corda (sic.)". Nessa perspectiva, a Assistente Social B entrevistada aponta que se trata de "um círculo vicioso: são outros serviços públicos que não funcionam e que resultam tudo na prisão e na segurança pública (sic.)"

Sobre a questão educacional, cerca de $65 \%$ dos relatórios que faziam menção do nível de escolaridade do sentenciado (total de 52) informavam que não possuíam o

${ }^{26}$ Dados segundo o Instituto Brasileiro de Geografia e Estatística - IBGE (1971). 
Ensino Fundamental completo. Desses, três casos relatavam que os sentenciados eram analfabetos. Houve nove incidências de efetivação de alguma série do Ensino Médio, ou 17,3\% e um caso de conclusão do Ensino Superior. Observou-se, ainda, que seis relatórios fizeram menção sobre a conclusão de alguma série no interior do presídio. Um relatório apresentou uma situação interessante: após concluir o Ensino Médio no presídio, o sentenciado prestou vestibular para engenharia na Universidade Católica de Brasília, tendo obtido a aprovação no exame, porém foi impedido de cursar a faculdade por estar cumprindo pena em Regime Fechado.

No que tange à profissionalização do recluso, 53 relatórios fizeram menção do trabalho que exerciam antes de cometerem o delito ou mesmo apresentaram informações sobre o aprendizado da profissão no presídio. Desses, a atuação na área da construção civil foi o que teve maior incidência. Profissões como pedreiro, ajudante de pedreiro, pintor, eletricista, serralheiro, servente, marceneiro, carpinteiro além de declarações do tipo "trabalhava em uma construtora" e "trabalhava na construção civil" foram considerados para efeitos estatísticos dessa análise. Essas respostas somaram um total de 16 , representando $30 \%$ das respostas. O trabalho informal foi assinalado em 13\% dos relatórios, essa taxa foi averiguada somente a partir das ocupações que notadamente não constituem qualquer vínculo empregatício para aquele que a exerce, a saber: carroceiro, vendedora ambulante, vendedor autônomo, flanelinha, vigia de carros e "fazia pequenos bicos". A opção "sem profissão" foi observada também em $13 \%$ dos casos. Ocupações ligadas a área de mecânica totalizaram 11\% das respostas e atuações como motorista ou Office boy corresponderam a 9\% das ocorrências. Os outros 24\% equivaleram a profissões com menos de 5 incidências, a saber: militar, secretária, açougueiro, serígrafo, fisioterapeuta, músico, artesão, costureiro, vendedor, oleiro, jardineiro, agricultor, além de respostas como "trabalhou em uma farmácia" e "trabalhou em uma empresa de refrigeração".

Ainda nesse aspecto, vale salientar que algumas dessas profissões mencionadas foram aprendidas no interior do Sistema Prisional, vide a de serígrafo e costureiro. No Distrito Federal, o trabalho e a assistência educacional do apenado - direitos garantidos na Lei de Execução Penal (seção IV do capítulo II e capítulo III) - são geridos pela Fundação de Amparo ao Trabalhador Preso - FUNAP, órgão vinculado à Secretaria de Segurança Pública do DF que tem como objetivo de contribuir para a recuperação social 
dos sentenciados e a melhoria de suas condições de vida. Na área educacional, a Fundação oferece instrução escolar da alfabetização até a preparação para ingresso no Ensino Superior. No que tange o trabalho, são ministrados cursos profissionalizantes de costura industrial, operador de microcomputador, artes cênicas, curso básico de padeiro, entre outros. Segundo dados do Relatório de Atividades do Distrito Federal de 2008, em dezembro daquele ano, 1.070 sentenciados estavam sendo ressocializados pela FUNAP por meio do trabalho e da educação.

A respeito de possíveis problemas de saúde enfrentados pelos sentenciados, o uso de álcool e/ou drogas foi observado em 35 dos 42 relatórios analisados que faziam menção a estes fatores. Um índice de quase $85 \%$ de incidência. $\mathrm{O}$ uso de entorpecentes se fez presente por meio das drogas mais conhecidas como cannabis sativa ou maconha, cocaína, merla e inalantes. Um caso a ser destacado é a utilização por uma sentenciada de remédios controladores de humor (antidepressivos) como droga através da ingestão de excessivas doses. Por causa dessas características, os encaminhamentos para os serviços substitutivos em Saúde Mental, leia-se Centro de Apoio Psicossocial - CAPS, destinado a usuário de álcool e drogas foi uma constante ao longo desses três anos. Fazendo um paralelo com a questão das drogas nível nacional, observou-se que, apesar de cada vez mais o Brasil apresentar casos de drogadição com substâncias com maior poder destrutivo como o crack, não foi registrado nenhuma ocorrência do consumo desse tipo de droga. Outros problemas de saúde registrados foram: taquicardia, AIDS, hipertensão, diabetes, mal de Parkinson, depressão, hérnia de disco, dores renais e estomacais - mais de uma dessas situações de saúde podem ter sido mencionadas num mesmo relatório.

Ainda sobre essa questão da Saúde, quatro relatórios fazem menção a falta de atendimento médico. A assistência à Saúde do apenado, prevista na Lei de Execuções Penais - LEP em seu capítulo II seção III, no Distrito Federal tem sérios ranços de ineficiência e baixa cobertura. Segundo Cardoso (2004), até fevereiro de 2004, no Centro de Internamento e Reeducação - CIR, os atendimentos médicos eram realizados por meio de ações voluntárias desses profissionais ou por meio de contratação de médicos que visitavam a unidade, mas que não tinham uma ação contínua, visto que a gratificação paga aos profissionais ser muito baixa. De acordo com o sítio da Secretaria de Saúde do Distrito Federal, o Sistema Prisional conta com 10 equipes 
multiprofissionais de saúde, composta por: médico, enfermeiro, auxiliar de enfermagem, cirurgião dentista, auxiliar de consultório dentário, psiquiatra, terapeuta ocupacional, psicólogo e assistente social que trabalham em turnos de 20h semanais, ou seja, há uma equipe de saúde de manhã e outra de tarde para mais de 7.000 sentenciados. Apesar desse quantitativo, Cardoso (2004) faz a ressalva de que os atendimentos priorizados são os médicos e odontológicos, nota-se uma pouca ciência dos serviços psicossociais os quais são deixados a margem visto o CIR contar com apenas dois agentes penitenciários para fazerem a escolta da carceragem até o centro de atendimento.

Um último exame dos relatórios indica que sete relatórios informam sobre a passagem do sentenciado pelo Centro de Atendimento Juvenil Especializado - CAJE durante a sua adolescência. Com relação ao objeto de análise desse estudo, observou-se que, dos 90 relatórios analisados, 18 ou 20\% fizeram menção a alguma Saída Especial nos feriados de Dia das Mães, Dia dos Pais, Dias das Crianças, Natal e/ou Ano Novo realizadas pelos sentenciados. Não foi encontrada qualquer ocorrência de Saída Especial de Páscoa. Quanto a questão reincidência, seis relatórios informam de alguma reincidência já cometida.

\section{Coleta De Dados}

Como segunda parte da coleta de dados para compreensão da percepção dos usuários e profissionais sobre o trabalho do Serviço Social, procedeu-se a realização de oito entrevistas no mês de Junho de 2009, a saber: i) quatro entrevistas com as Assistentes Sociais lotadas na Seção Psicossocial da Vara de Execuções Penais SEVEP que atuam junto a casos de sentenciados em Regime Semi-Aberto nos benefícios de Trabalho Externo e Saídas Temporárias; ii) uma entrevista de grupo focal, ou simplesmente grupo focal, com os empregadores e/ou familiares dos sentenciados; iii) entrevista conjunta com duas familiares de um mesmo sentenciado; iv) duas entrevistas com as genitoras de dois sentenciados. Cada entrevista foi precedida de um momento de observação dos atendimentos e grupos realizados pelas Assistentes Sociais.

Antes de se proceder a análise das informações coletadas, faz-se necessário esclarecer alguns pontos de metodologia de pesquisa. Primeiramente, é preciso salientar 
que a todos(as) entrevistados(as) foi garantido o anonimato por meio da assinatura de Termo de Consentimento Livre e Esclarecido - TCLE em anexo. Por se tratar de um contexto de Justiça, com sujeitos em situação de vulnerabilidade, as entrevistas com os usuários e mesmos as observações não puderam ser gravadas. De acordo com informações de um gate keeper, para que a gravação fosse possível, o projeto de pesquisa deveria ser encaminhado ao Juiz da Vara de Execuções Penais para que fosse analisado e posteriormente dado parecer, com significativas possibilidades de indeferimento do estudo. Portanto, as entrevista gravadas foram aquelas realizadas com as Assistentes Sociais. Todo o procedimento metodológico foi realizado na SEVEP com a contribuição das profissionais que dispuseram o ambiente físico para a execução das entrevistas.

\section{As Observações}

A observação como estratégia de ação visa o conhecimento preliminar do campo de pesquisa, abarcando sujeitos e espaço. Neste trabalho a utilização dessa metodologia se orienta para a apreciação dos atendimentos realizados pelas Assistentes Sociais junto à famílias e/ou empregadores de sentenciados. Um total de quatro atendimentos foram acompanhados, sendo que três desses objetivavam o estudo social para a concessão do benefício de Saídas Temporárias; e o quarto se configurava como o atendimento de empregadores visando a análise de proposta de trabalho para fins de concessão do benefício de Trabalho Externo.

Seguindo a ordem cronológica, o primeiro atendimento a ser observado foi o de grupo de empregadores em que constavam seis participantes, sendo mediado por duas Assistentes Sociais - apenas uma delas direcionou o grupo. Inicialmente, as profissionais informaram a cerca da função da Seção Psicossocial em analisar os

aspectos subjetivos da pena bem como ressaltaram que o objetivo desse tipo de intervenção se inscreve na mediação entre Juiz, empregadores e sentenciados.

Posto isso, foi requisitado que os empregadores se apresentassem, declarando seus nomes, a que sentenciado estavam oferecendo a proposta, em qual função iriam atuar e se tinham algum vínculo familiar com o apenado. Após esse momento, constatou-se que todos os presentes possuíam algum tipo de parentesco com o 
sentenciado, seja de forma direta ou indireta (um caso em que o sócio do empregador presente era pai do interno). Essa primeira observação retoma a análise feita anteriormente que coloca a família como alvo da proteção social de seus componentes. Aliado a esse fator, o estigma de preso que carregam esses indivíduos contribui em tudo para o comparecimento cada vez maior de familiares na condição de empregadores dos sentenciados.

Prosseguindo a análise do atendimento, procedeu-se a leitura das regras do benefício de Trabalho Externo, que tratam-se de um misto de informações constantes na Lei de Execuções Penais a partir do art. 29 e na Consolidação das Leis do Trabalho (apesar de como verificado acima essa população não está submetida a esse regime). Um aspecto interessante dessa parte do atendimento se insere na perspectiva da remuneração do sentenciado, a Assistente Social declarou que muitas denúncias foram feitas sobre o não pagamento de salário a esses indivíduos. Avalia-se que muitos empregadores que se dispõem a oferecer um emprego o fazem como um mero ato de caridade, no sentido em que, segundo suas percepções, aquele trabalho escravo a que o apenado é submetido faz parte da pena a ser cumprida. Por outro lado, a profissional também informou de casos em que mesmo tendo sido confirmado o fato, muitos dos sentenciados não desejam que seja feita a denúncia, pois analisam que a liberdade como bem maior que deve ser adquirida independente das condições subumanas a que sejam submetidos, já que nada se compara ao presídio em termos de violação dos seus direitos.

Nessa perspectiva, sabendo desse desejo do sentenciado em se ver livre, e contraditoriamente compreendendo as formas precárias de trabalho que se encerram na nossa sociedade moderna, a Assistente Social faz menção sobre outras formas de contratação do sentenciado que não as claramente permitidas já que, como informado acima, muito dos empregadores não querem ou não podem contratar o sentenciado por no mínimo $3 / 4$ do salário mínimo. Dentre estas possibilidades, destaca-se uma gama de trabalhos realizados por meio de contrato que por vezes não garante a assinatura da carteira de trabalho, bem como qualquer direito social garantido aos trabalhadores (vide direitos previdenciários). 
Antes de se proceder a análise das propostas de trabalho individualmente, a Assistente Social ao longo do momento em grupo, ressaltou algumas informações: primeiramente, a reincidência criminal para trabalhadores via Fundação de Amparo ao Trabalhador Preso - FUNAP é cerca de $75 \%$ maior do que aquela para empregados via proposta particular. A técnica analisa que isso se dá devido a dois motivos: a) o não acompanhamento sistemático do sentenciado pelo seu empregador, já que este é difuso - o Estado; b) além da aglomeração de sentenciados no mesmo local. Em segundo lugar, a profissional destacou que metade dos sentenciados que se encontram hoje no Centro de Progressão Penitenciária - $\mathrm{CPP}^{27}$ foram encaminhados para esse presídio via proposta de empregador particular ${ }^{28}$.

Partindo para os próximos atendimentos observados, analisar-se-á três procedimentos junto à familiares, realizados entre os dias 18 e 22 de junho do presente ano. A princípio, como explicitado no capítulo a cerca dos processos de trabalho do Assistente Social na SEVEP, este atendimento tem o objetivo de, nos dizeres da própria Assistente Social mediadora, "analisar as condições familiares" do sentenciado. A técnica informa em seguida como se dará o atendimento realizado junto a família, a saber: aquele presente momento conjunto com familiares somente de um sentenciado, seguido do grupo de familiares com outros acolhidos que participaram também de atendimentos individuais com uma psicóloga ou Assistente Social com vistas a proceder a leitura das regras do benefício de Saídas Temporárias. O terceiro atendimento descrito diferencia-se por não ter sido seguido de um momento em grupo, motivo pelo qual todas as informações foram prestadas em um único momento.

No atendimento individual é preenchido um questionário aplicado e respondido pela própria profissional a partir das informações prestadas pelas entrevistadas. Com base na análise do instrumental, verificou-se que as informações coletadas traçam um perfil do sentenciado - idade, escolaridade, trabalho realizado antes de ser preso, filhos, estado civil, condições de saúde (drogas e alcoolemia), etc. - além de estabelecer

\footnotetext{
${ }^{27}$ O Centro de Progressão Penitenciária é o presídio no Distrito Federal destinado ao cumprimento do Regime Semi-Aberto.

28 A veracidade das informações prestadas é de total responsabilidade da profissional.
} 
informações a cerca das relações familiares ou de amizade que o/a entrevistado/a tem com o apenado.

No primeiro atendimento, a participante era a genitora do sentenciado. Declarou, esta, que teve três filhos - dois homens e uma mulher. A entrevistada informou que os dois homens cumprem pena. Sobre o sentenciado alvo do atendimento, esta informou que ele cursou até a quinta série do Ensino Fundamental, tendo, logo em seguida, começado a exercer atividades laborais como ajudante de pedreiro e instalador de aparelhos sonoros, porém nunca teve sua carteira de trabalho assinada.

A genitora relatou, ainda, que o apenado fazia uso de álcool, porém não soube informar se ele também era usuário de drogas. A entrevistada atribuiu o fato delituoso às más companhias e ao fato da família não estabelecer um local fixo de residência, o que teria feito com que seus filhos optassem por evadir da escola.

Prosseguindo a descrição da entrevista, a informante declarou que o apenado está recluso há 3 anos e que nunca usufruiu de qualquer benefício de saída. Sobre a vida intramuros do sentenciado, relatou que ele parece estar arrependido do fato delituoso e que parece estar trabalhando e estudando.

A partir das informações prestadas pode-se observar que se tratou de um atendimento bem típico da Seção Psicossocial: a presença da genitora, a pouca escolaridade do sentenciado, o trabalho como ajudante de pedreiro, a precariedade da forma de contratação e a alcoolemia.

No atendimento seguinte estavam presentes a genitora e a avó materna do apenado. Não foi a primeira vez que haviam sido convocadas, no atendimento anterior foi feita a entrevista com uma psicóloga sendo que somente a genitora havia participado, porém como ela não iria receber o sentenciado o juiz demandou que fosse feito um segundo atendimento com a pessoa que se dispusesse a recebê-lo. Inicialmente, segundo a percepção da mãe do interno, este era de difícil convivência e que, juntamente com outro irmão, foram albergados durante um tempo a pedido da genitora e com mediação do conselho tutelar.

As condições de saúde do apenado, assim como das entrevistadas foram o que mais chamou atenção: casos de epilepsia, dores fortes na coluna, tuberculose e 
problemas dentários revelam os precários serviços médicos dispostos a população. Como mais uma expressão da questão social, o arrefecimento da saúde das classes pobres indicam a representação de uma sociedade que cada vez mais explora e maltrata seus trabalhadores.

Outra característica interessante desse atendimento diz respeito a postura da Assistente Social, o caráter aliviador de tensões e sentimentos do procedimento ficou patente quando a profissional investiu numa tentativa de reaproximação afetiva entre a genitora e o sentenciado. Ao citar a importância da família na ressocialização do preso, a Assistente Social disse: "por mais que a gente cometa erros, Deus nos deu a capacidade de perdoar" (sic.).

O terceiro atendimento realizou-se no dia 22 de junho e, como informado acima, não foi seguido de grupo de familiares. A entrevistada era a mãe adotiva do sentenciado. Informou que não tem o costume de visitar o sentenciado, visto que para fazê-lo são muitos gastos com transporte e mesmo com o acompanhante que como mesmo ela disse: "eu tenho que dar um 'agrado' para o motorista porque eu não tenho habilitação e ninguém vai querer ficar comigo lá o dia inteiro" (sic.).

Declarou que a sua prole foi de cinco, sendo duas mulheres e três homens, destes dois são adotivos. A dinâmica familiar pode ser descrita da seguinte forma: a filha mais nova estuda, a outra filha é casada e não vive mais na mesma residência com a família, os outros dois filhos não têm emprego fixo - de acordo com a declaração da entrevistada "[estes] faziam uns bicos de jardinagem lá pra chácaras mesmo" (sic.) soma-se a esse conjunto o apenado que antes de cometer o delito nunca trabalhou "fichado", tendo exercido atividades como entregador e agricultor.

Visivelmente precária as condições de mantença da família, o trabalho formal não faz parte de suas realidades. Além do que a entrevistada informou que recebe $\mathrm{R} \$ 130,00$ de renda mínima, que segundo sua percepção "não é muita coisa mas é melhor que nada" (sic.). A sociedade salarial dos anos 1970 foi dilacerada com o tempo, em seu lugar surgiram programas de assistência social que ao invés de acabarem com "o ciclo geracional da pobreza" criam um processo de filiação perversa e estigmatizante.

A conclusão que se pode tirar das observações realizadas é que 
"Os assistentes sociais trabalham com a questão social nas suas mais variadas expressões quotidianas, tais como os indivíduos as experimentam no trabalho, na família, na área habitacional, na saúde, na assistência social pública, etc. Questão social que sendo desigualdade é também rebeldia, por envolver sujeitos que vivenciam as desigualdades e a ela resistem, se opõem. É nesta tensão entre produção da desigualdade e produção da rebeldia e da resistência, que trabalham os assistentes sociais, situados nesse terreno movido por interesses sociais distintos, aos quais não é possível abstrair ou deles fugir porque tecem a vida em sociedade. [...] ... a questão social, cujas múltiplas expressões são o objeto do trabalho cotidiano do assistente social" (IAMAMOTO, 1997:14).

Essa citação objetiva apontar que, independente do espaço sócio-ocupacional que se atue, o Serviço Social como profissão atua nas mais diversas expressões da questão social. Apesar da partilha que as vezes se intenta fazer, essas expressões, como diz Iamamoto "rebeldes" que as são e integrando o indivíduo em sua totalidade, fazemse presente nas mais diversas intervenções do assistente social.

\section{As Entrevistas}

Prosseguindo com a análise de dados, essa segunda parte apresentará as informações coletadas por meio das entrevistas e grupo focal realizados. Vale lembrar que como informado anteriormente, os procedimentos que envolviam os usuários da Seção Psicossocial não puderam ser gravados, porquanto, que análises de dados advindas destes se insere no âmbito das anotações realizadas (falas, comentários, intervenções e atmosfera das relações que se processaram). Primeiramente, serão analisados os dados coletados no grupo focal e nas entrevistas realizadas, seguindo esta ordem. Posteriormente, as quatro entrevistas com as Assistentes Sociais serão alvo de apreciação.

O grupo focal foi realizado com os empregadores - e como visto anteriormente, familiares - dos sentenciados. Segundo Gomes e Barbosa (1999) "o grupo focal é um grupo de discussão informal e de tamanho reduzido, com o propósito de obter informações de caráter qualitativo em profundidade”. Esta técnica intenta identificar as percepções, sentimentos e idéias dos participantes sobre determinado assunto, averiguando o aspecto da sinergia do grupo em gerar o debate mais profícuo do que entrevistas individuais. Segundo Dias (2000), a utilização do grupo focal é vantajosa 
quando o público alvo da pesquisa é analfabeto ou com dificuldades de leitura e compreensão - excluindo-se a possibilidade do uso de questionários escritos - e, em se tratando de comparar a entrevistas individuais, essa técnica é relativamente menos dispendiosa em termos de custo e tempo tanto para o mediador quanto para aqueles que participam do grupo.

Explicitado o motivo da utilização desta técnica, dos dois grupos focais inicialmente propostos a serem executados, somente um pode efetivamente ser realizado, pois como uma das desvantagens dessa metodologia: a sua utilização demanda a conjugação da vontade de todos os entrevistados em poderem participar.

Como posto acima o instrumental foi aplicado com empregadores/familiares, estavam presentes cinco sujeitos que prontamente se interessaram por participar do grupo. Este se revelou como sendo um momento de grande debate entre os presentes a cerca da temática do trabalho como ressocializador do indivíduo. O que se avaliará a seguir são as tendências dos participantes no trato das questões apresentadas.

Inicialmente, quis-se abordar como os participantes avaliavam o trabalho das Assistentes Sociais, anteriormente executado, como fonte de mediação entre empregador e a função deste como contribuinte na ressocialização dos sentenciados.

Os participantes apresentaram perspectivas positivas quanto a esse questionamento. Informaram que na perspectiva da orientação, o trabalho do Assistente Social em tudo pode contribuir para a reintegração do apenado e por conseguinte evitar que este venha a recair nas malhas da Justiça como reincidente ou mesmo como foragido. Duas Senhoras presentes destacaram que aquele momento é único para que tenham conhecimento dos direitos e deveres que têm para com o sentenciado. Os participantes declararam, ainda, que as informações adquiridas seriam de grande importância para o disciplinamento e chamamento à responsabilidade do apenado.

Quanto a pergunta sobre o papel do trabalho no retorno ao convívio social dos internos, declararam que é muito importante, pois consideram que os sentenciados se encontram na situação de devedores da sociedade porque "não tiveram oportunidade" (sic.). Mais do que isso, o trabalho "faz com que eles criem responsabilidade", essa afirmação faz clara aferição às condições individuais como únicas responsáveis pela condição de empregados ou desempregados. É observável como, ideologicamente, 
mesmo as populações excluídas introjetam em suas análises assertivas de cunho dominante-burguesa quanto, pelo menos, aos princípios do trabalho, ou seja, não se trabalha por que é preguiçoso.

Quando levantado o debate da desassistencialização do Estado (pergunta $n^{\circ} 01$ do guia de entrevista focal) para com a população vulnerável como forma de coação desses sujeitos para a única resposta possível, qual seja: o crime, uma fala coletada muito interessante quanto as reações do Estado por meio de um maior aparato repressivo a essa dita criminalidade e a culpabilização do indivíduo pela violência, afirmou que

"Eu culpo o Estado sim, por acaso ele deu escola, saúde pro pessoal lá da Estrutural? Ele não deu nada e depois quer cobrar. (...) Ele não cumpriu com a parte social, não tem posto de saúde, escola descente na Estrutural!”

Devido ao avançar da hora e a necessidade das Assistentes Sociais em continuarem os procedimentos de trabalho, o grupo focal foi encerrado. Uma última análise que talvez fuja um pouco o âmbito dessa pesquisa, mas vale salientar é que uma das participantes em nenhum momento soube diferenciar assistente social de psicólogo, identificando mesmo a pesquisadora como graduanda em Psicologia.

Passando para a análise das entrevistas com familiares que objetivavam o atendimento para concessão de benefício de Saídas Temporárias para seus filhos, serão retomadas as perguntas feitas no grupo focal buscando assim as impressões coletadas. Nessa parte da análise é preciso observar que houve uma perda de informações, visto que dos três atendimentos observados, uma das genitoras não se dispôs a ser entrevistada, pois necessitava tomar o transporte público com horário fixo para retornar à sua residência. As Senhoras que se dispuseram, então, a participar da pesquisa foram aquelas presentes no segundo e terceiro atendimentos individuais observados, ou seja, genitora e avó de um sentenciado; e a genitora do outro interno. Com vistas à manutenção do anonimato e maior clareza na análise dos dados, a cada uma das participantes será atribuída uma letra, assim sendo: genitora e avó do primeiro atendimento, A e B, respectivamente; segunda genitora, a letra $\mathrm{C}$. 
As participantes destacam-se, porém, por, no decorrer do atendimento, informarem que seus filhos, um teve passagem pelo Centro de Atendimento Juvenil Especializado - CAJE, e o outro foragiu por ocasião de Saída Especial de Dia das Mães.

Inicialmente com relação a pergunta qual a percepção dos Senhoras sobre a situação que levou o parente ou amigo de vocês a se tornar um sentenciado? A resposta foi unanime em dizer que foram as "más amizades". Problematizando um pouco, essa questão das "amizades" percebe-se, em suas falas, que tratam-se de menores que, na maioria das vezes em horários contrários ao dos estudos (isso se ainda estudavam), não têm qualquer atividade a ser realizada, seja esportiva ou cultural. Veja bem, o objetivo de formatar essa configuração dessas amizades, que em muito lembra os chamados "rapazes de esquina" do antropólogo Foote Whyte, não é realizar uma proposta estigmatizante e preconceituosa mas salientar que essa falta de opção em termos de divertimento impede ações instrutivas de formação do indivíduo.

Nesse ponto, as entrevistadas salientaram ainda como a prisão dos apenados se deu de forma arbitrária e intransigente. Como afirma o Direito Penal, o cidadão somente pode ser preso em caso de flagrante delito, porém em nenhuma das situações apontadas pelas familiares assim se deu a reação policial. Caracteriza-se uma ideologia que a entrevistada C aponta como "se pobre, então é ladrão" (sic), ou como apontado pela participante A, fazendo a ligação da temática com o provérbio popular "a corda sempre arrebenta do lado mais fraco" (sic).

Sobre a perspectiva de que forma a execução penal (re)socializa esse indivíduo? As entrevistadas interpretaram execução penal como prisão e dessa forma disseram que esta instituição de nenhuma forma pode ajudar na ressocialização, afinal "a prisão não é lugar pra gente, aquilo lá é desumano" (entrevistada B). Porém avistaram alguma possibilidade de apoio no que tange as visitas realizadas pela família ao apenado. Retoma-se, aqui, a noção da prisão como apenas um espaço de segregação do indivíduo que em pouco ou nada contribui para o seu retorno ao convívio social, porquanto que a analise apontada pelas participantes vai de encontro ao que por muito tempo vem se perpetuando na sociedade: "prisão é a universidade do crime". A família também é apontada como espaço primeiro e único de formação e responsabilidade pelos seus componentes. 
Retomando as informações prestadas pelas entrevistadas quanto a fuga em Saída Especial e passagem pelo Centro de Atendimento Juvenil Especializado, as duas genitoras discorreram sobre um sentimento de medo que seus filhos sentiram por ter que retornar ao presídio, optando ou por evadir ou por deixar de se apresentar.

As entrevistadas ressaltaram, ainda, como o tratamento dispensado a essa família por vezes não é nada digno, a noção de que "porque é parente de preso, também é bandido" (entrevistada B) está bastante incutida, segundo avaliam as participantes, na forma como os agentes penitenciários e mesmo a sociedade, como um todo, olha para esses familiares. "Isso derruba o moral!" (entrevistada A) disse a entrevistada sobre como se dá as revistas penitenciárias. A entrevistada B ainda aprofundou sobre a sociedade que se organiza intramuros, destacando o sistema de regras entre os próprios presos:

"lá cada um tem o seu canto, a gente fica com um espaçinho assim e não pode olhar pro lado, porque vai que algum preso não gosta, aí depois eles vão querer tirar satisfação com ele [disse o nome do sentenciado]" (sic.).

Em seguida foi questionado se $o$ atendimento com a Assistente Social de alguma forma pode contribuir para a (re)socialização desses sentenciados? Nesse sentido, informaram que os atendimentos foram excelentes e que o grande ganho que tiveram foi a orientação que receberam, a participante $C$ mencionou que não tinha conhecimento das informações repassadas pela Assistente Social e que ela ter vindo acabou sendo de grande valia. Outra participante mencionou ainda o caráter aliviador que o atendimento proporcionou: "eu tava meio pra baixo e o atendimento com a Assistente Social me fez ficar melhor" (entrevistada A).

A última questão que teve por objetivo chegar ao cerne do objeto de estudo trouxe informações contundentes. Todas as entrevistas afirmaram do caráter informativo dos atendimentos em que participaram, porém as participantes A e B interpretaram, diferentemente da terceira entrevistada, a forma como essas informações podem ser um primeiro passo para a emancipação do sujeito apenado. Ao responderem diretamente a pergunta: você vê alguma ligação entre a atuação da Assistente Social na SEVEP e os baixos índices de reincidência e foragidos no Distrito Federal? As primeiras foram claras ao afirmar que 
"Sim, é bom pra gente levar lá pra eles [presos]. Agora a gente sabe o que que a gente tem que fazer pra ajudar eles." (sic.).

Ao passo que a terceira entrevistada respondeu

"Acho que não, minha filha, aqui a gente recebe mais informações, mas se eles decide reincidir não tem nada a ver com aqui” (sic.)

Uma última afirmação prestada por uma das entrevistadas diz respeito a sua percepção com a reincidência pode ser mais uma questão mais sensível nos ditos crimes sexuais, quais sejam: estupro, atentado violento ao pudor, violação sexual mediante fraude, atentado ao pudor mediante fraude, assédio sexual, sedução, estupro de vulnerável, corrupção de menores, satisfação de lascívia mediante presença de criança ou adolescente e favorecimento da prostituição ou outra forma de exploração sexual de vulnerável.

Fica claro, portanto, que por parte dos familiares o caráter do atendimento com a Assistente Social é muito mais instrutivo, visto ser um acompanhamento único em que a possibilidade de atribuir grandes implicações (e porque não, responsabilidades) a esse trabalho é quase nula.

Partindo para a análise das entrevistas realizadas com as profissionais da Seção, buscou-se averiguar a interpretação destas sobre o trabalho que realizam, de que forma o avaliam e, tendo sabido dos índices de Foragidos no Distrito Federal e o número de sentenciados reincidentes reclusos, se suas impressões permaneciam as mesmas. Para fins de melhor averiguação, cada uma das quatro entrevistadas será designada por uma letra, assim sendo: A, B, C e D. A análise será realizada com base nas perguntas feitas.

Primeiramente, faz-se necessário a apresentação das Assistentes Sociais entrevistadas com base em tempo de atuação na Profissão, tempo de atuação na SEVEP e tempo de intervenção com apenados imputáveis.

A Assistente Social A já atua como profissional desde 1998, tendo iniciado a sua intervenção na Seção Psicossocial em novembro de 2001 sempre trabalhando com réus comuns. 
A Assistente Social B formou-se em 2007, sendo que há 10 meses iniciou a sua atuação na SEVEP. Informou que no momento trabalha quase que exclusivamente junto ao benefício de Trabalho Externo.

A Assistente Social C iniciou sua intervenção profissional há 10 anos, sendo que há 2 meses foi lotada na Seção Psicossocial. Assim como a Assistente Social B, sua atuação se insere no âmbito da avaliação das propostas de trabalho para fins de concessão de Trabalho Externo.

A Profissional D atua como Assistente Social desde 2003, sendo que há 3 meses intervém na SEVEP junto aos benefícios de Saídas Temporárias.

Como as primeiras questões do roteiro de entrevista são um tanto quanto mais ilustrativa, e objetivam somente averiguar algumas características desse espaço de atuação, elas não serão instrumento de nossa análise aqui. As questões que terão argüição iniciam-se da pergunta número 4:

- Fale-me dos usuários do Serviço Social na Seção Psicossocial da VEP: demanda espontânea? demanda interna ou externa?

A Assistente Social A não apontou claramente essa configuração dos sujeitos que demandam serviços na Seção Psicossocial. Mas informou que o usuário é basicamente o sentenciado em suas múltiplas necessidades de saúde (comenta a questão da drogadição), educação e trabalho.

As Assistentes Sociais B e D formularam um possível perfil dos sentenciados que é bastante condescendente com àquele levantado a partir da análise dos relatórios apresentada anteriormente: pobreza, pouca escolaridade e formas precárias de inserção no mercado de trabalho.

\footnotetext{
"é um circulo vicioso: são outros serviços públicos que não funcionam e que resultam tudo na prisão, na segurança pública (...). É um perfil de extrema miséria" (Assistente Social B).
}

Nessa perspectiva, a Assistente Social C declarou que se procede uma relação contraditória de inversão dos fatos, isto é,

"Quando uma pessoa não é incluída, ela pratica um crime aí a partir daí ela passa ser incluída" (Assistente Social C). 
Nesse sentido, como bem apresentado pela Assistente Social B, se intenta uma dita ressocialização, sendo que efetivamente nunca houve uma inclusão, uma integração daquele indivíduo. Vale salientar que dados do INFOPEN - Sistema de Informação Penitenciária, sobre o "Perfil do Preso" informam que, na sua maioria, trata-se de indivíduos com o Ensino Fundamental Incompleto, com penas de 4 a 8 anos, que cometeram crime de roubo qualificado (Código Penal - Art. 157), entre 18 e 24 anos e de cor parda.

Prosseguindo para a próxima pergunta como a Senhora analisa a sua intervenção junto aos sentenciados, família elou empregadores?

A Assistente Social A apontou com grande entusiasmo que o seu trabalho tem efetivos impactos na ressocialização de sentenciados ao convívio social a partir do momento em que o atendimento busca preparar a família e, às vezes o sentenciado, para esse reencontro. Avaliou que sua intervenção é sempre pautada nos ideais de humanização e justiça social com vista a efetivação dos direitos dos sujeitos.

"A minha intervenção junto ao interno, sentenciado ou apenado, eu avalio ela como uma intervenção pensando na justiça social, na humanização, o objetivo de humanizar e preparar eles pra uma vida que provavelmente não vai ser diferente daquilo ele encontrava antes de ser preso. Muitas vezes a realidade familiar não muda. Mas a proposta é sempre da inclusão" (Assistente Social A).

As Assistentes Sociais B e C, contrariamente, apontaram que os efeitos contributivos de suas atuações para os usuários são muito reduzidos devido aos atendimentos não serem uma ação continuada e permanente. Encaram os atendimentos junto a famílias com um espaço muito mais de acolhimento do que de reflexão profunda em prol de mudanças a curto prazo.

"O espaço de tempo é muito curto pra eles refletirem sobre o crime, sobre essa situação do sentenciado. (...) Acho que a informação é o principal foco" (Assistente Social B)

Posto isso, no entanto, as entrevistadas B e C atribuíram aspecto ressocializador ao atendimento que objetiva a concessão do benefício de Trabalho Externo. Declararam que se o sentenciado tem a possibilidade de retornar ao convívio social por meio de alguma atividade laborativa, este terá menos chances de reincidência e evasão já que uma enorme gama de apenados ao deixarem o Sistema Prisional se verão 
desempregados e com uma dificuldade ainda maior de inserção devido ao estigma que carregam.

A entrevistada D, por sua vez, vê aspectos positivos de seu trabalho, porém não no momento do atendimento, mas na elaboração do relatório social em que há espaços para encaminhamentos que visem a inclusão do apenado e a concretização de seus direitos.

"A intervenção se faz no momento do relatório, que a gente tem a oportunidade de sugerir algumas coisas para a inserção e ressocialiazação do preso. A gente percebe que aqueles encaminhamentos têm retornos" (Assistente Social D).

Partindo para uma pergunta importante para análise de dados, foi questionado como as entrevistadas avaliavam o trabalho realizado. Qual a importância de ele ser executado para a sociedade e se de alguma forma isso poderia influenciar nos índices de foragidos e reincidência no Distrito Federal. As respostas coletadas foram

Por parte das Assistentes Sociais A e D convergiam em suas respostas ao afirmarem que a grande importância do trabalho executado se insere na esfera da mediação entre os atores e a instituição Judiciária, isto é, interpretam que todo o aspecto orientativo do atendimento tem porquê de sê-lo pois é desta forma que se produz cidadania, através da informação. Em outros temos, a conscientização do indivíduo ou, minimamente, o começo de uma reflexão sobre a realidade em que se insere, de maneira nenhuma impede que este exercício possa ser concretizado em outros espaços (comunidade, associações, igrejas, etc.). A construção da autonomia dos sujeitos é que faz da intervenção do Serviço Social na Vara de Execuções Penais um instrumento importante.

"Na linha do trabalho, a importância dele é ser realizado é ser um link para o Juiz com o preso, com réu preso, com a Justiça. A gente decodifica essa lei para as famílias, para os presos... Sou uma voz entre eles, nessa esfera tão difícil dos direitos, da Justiça, de como ela funciona. Então a grande importância que eu falo sempre pra essa seção, é estar fazendo isso com essas famílias: a mediação, a articulação é usar essa situação com eles" (Assistente Social A).

As assistentes sociais $\mathrm{B}$ e $\mathrm{C}$ reforçaram que em um único atendimento pensar em construir uma reflexão profunda é um tanto ambicioso. Declararam que este não é o 
objetivo do atendimento, mas sim recolher informações que possam subsidiar a decisão do Juiz e, talvez, orientar os usuários quanto aos aspectos da Execução Penal.

"Acho que é muito rápido o contato. Pelo menos das vezes que eu fui lá no presídio fazer as entrevistas, a gente já vai com o objetivo definido, a gente fala mais alguma coisa pra tentar refletir um pouco e pronto" (Assistente Social C).

Apesar das divergências encontradas quanto a percepção dos impactos do trabalho da Assistente Social na SEVEP, percebe-se nitidamente que de alguma forma parte do trabalho que executam tem grande valia para a Execução Penal, seja na esfera da mediação, da criação de redes, na humanização da pena por meio dos encaminhamentos propostos pelas Assistentes Sociais. Se numa analise mais aparente se apreende que os próprios Assistentes Sociais não vêem impactos dos seus trabalhos, pelo menos não no que concerne a reincidencia criminal e a evasão, uma análise mais profunda das interpretações latentes observa que de alguma maneira as entrevistadas apontam perspectivas positivas que auferem um horizonte de mudança no emancipação do sujeito apenado do Sistema Penitenciário. 


\section{CONSIDERAÇÕES FINAIS}

Em tempos de arrefecimento da questão penitenciária no Brasil; constantes violações dos direitos humanos dos presos; maior exposição da mídia da temática; além da aproximação da I Conferência em Segurança Pública do Brasil, este estudo buscou apresentar as principais perspectivas da atuação da Assistente Social na Vara de Execuções Penais do Distrito Federal. Configurando-se como um trabalho único e pioneiro no país, a percepção dessa intervenção profissional por parte dos seus agentes e dos usuários mais do que nunca necessitava de ser alvo de debates para que assim se pudesse proceder a uma análise efetiva dos alcances objetivados por esse trabalho.

Averiguou-se que as mediações que levaram a criação da Seção e o contexto em que esta se insere diversificaram profundamente ao longo dos anos. Isso equivale a dizer que a atuação profissional também sofreu significativas mudanças: a maior quantidade de usuários a serem atendidos, a crescente demanda pela criação de uma rede que atenda aquele sujeito ali presente na sua totalidade, a questão dos crimes sexuais, a precariedade de atendimento das condições de vida do apenado, entre tantas outras manifestações da questão social que apontam para um aprofundamento das desigualdades.

Apesar da hipótese de pesquisa: "o trabalho da Assistente Social contribui para os reduzidos índices de reincidência e foragidos" ter sido refutada, ao menos no nível da aparência, este estudo concluiu que, não sendo observado como uma via de mão única, a reincidência criminal e a fuga têm várias motivações para sua efetivação e que, na medida em que se atua para minimizar essas motivações proporcionando a orientação das famílias sobre como se pode proceder ao retorno do sentenciado à sociedade, a intervenção profissional pode contribuir de maneira adjacente na causa.

Alguns estudos que podem ser propostos com relação a temática são: a) a averiguação da hipótese junto aos próprios sentenciados internos; b) a averiguação da temática junto a reclusos recapturados depois de foragidos e mesmo junto a reincidentes; c) uma análise sociológica mais aprofundada sobre como se configura a criminalidade no Distrito Federal, intentando apreender o chamado "crime organizado" na unidade da federação; d) a construção desse tipo de análise com base nas 
especificidades da Psicologia, já que essa é também uma categoria profissional que atua na área..

Posto isso, espera-se que de alguma forma esta pesquisa possa ter efetiva aplicações no contexto da Seção Psicossocial e que proporcione um maior reconhecimento do trabalho único realizado. Ampliando mais os horizontes, esperanças são postas para que essa intervenção seja ampliada não somente no Distrito Federal, mas também em todo o país. 


\section{REFERÊNCIAS BIBLIOGRÁFICAS}

ALVES, G. A. P. . Dimensões da Reestruturação Produtiva - Ensaios de sociologia do trabalho. 2. ed. Londrina: Editora Praxis, 2007. v. 1. 298 p.

ARGÜELlO, Katie ; SÁ, A. A. de ; SCHRITZMEYER, A. L. P. ; SCHMIDT, A. Z. ; THOMPSON, Augusto ; BITENCOURT, C. R. ; SANTOS, J. C. ; NIÑO, Luis Fernando ; OLIVA, Marcio Zuba de ; RIOS, R. S. ; CARVALHO, Salo ; BITTAR, W. B. ; ARGÜELLO, Katie . Do Estado Social ao Estado Penal: invertendo o discurso da ordem. In: BITTAR, W. B.. (Org.). A Criminologia no século XXI. $1^{\text {a }}$ ed. Rio de Janeiro: Lumen Juris, 2007, v. , p. 119-144.

BARBOSA, R. N. C. ; ALMEIDA, N. L. T. ; CARDOSO, F. . A categoria Processo de Trabalho e o trabalho do assistente social. In: Serviço Social e Sociedade, Editora Cortez - São Paulo, v. 00, n. 58, p. 109-130, 1998.

BEHRING, Elaine Rossetti ; BOSCHETTI, Ivanete . Política Social: Fundamentos e História. 1. ed. São Paulo: Cortez Editora, 2006. v. 1. 213 p.

BRASIL. Lei de Execução Penal. Lei nº 7.210 de 11 de julho de 1984.

.Código Penal. Decreto-Lei n. ${ }^{\circ}$ 2.848, de 7 de Dezembro de 1940.

. Ministério da Justiça, Sistema Integrado de Informações Penitenciárias InfoPen. Relatórios Estatísticos - Analíticos do Sistema Prisional. Brasília, jun. 2008.

Câmara dos Deputados. Relatório Final da Comissão Parlamentar de Inquérito do Sistema Carcerário Brasileiro. Brasília, jun. 2008.

BRASÍliA. Secretaria de Estado de Planejamento e Gestão. Prestação de Contas Anual do Governador - Relatório de Atividades do GDF - 2008. Brasília, [s.d.].

jul. de 2009 .

. Portaria $\mathrm{n}^{\circ}$ 07, de 29 de abril de 2009. Diário da Justiça Eletrônico, 13 de

CARDOSO, M. C. V. A cidadania no contexto da lei de execução penal: o (des) caminho da inclusão social do apenado no sistema penitenciário do Distrito Federal. Brasília: Programa de Pós Graduação em Política Social / Universidade de Brasília, Dissertação de Mestrado, 2006.

CASTEL, Robert. As metamorfoses da questão social - uma crônica do salário. 4. ed. Petrópolis: Vozes, 2003.

CFESS. Assistente Social: ética e direitos. Coletânea de Leis e Resoluções. 2004.

CHESNAIS, François. A mundialização do capital. São Paulo: Xamã, 1996. 
CRUZ NETO, O.; MOREIRA, M. R.; SUCENA, L. F. M. Grupos focais e pesquisa social qualitativa: o debate orientado como técnica de investigação. In: XIII Encontro da Associação Brasileira de Estudos Populacionais - ABEP, 4 a 8 de novembro de 2002, Ouro Preto. Anais... Ouro Preto, 2002. Compact Disc.

DIAS, Claudia Augusto. Grupo focal: técnica de coleta de dados em pesquisas qualitativas. Informação \& Sociedade: estudos, João Pessoa, v. 10, n. 2, p. 141-158, 2000.

ENGELS, F. A Origem da Família, da Propriedade Privada e do Estado. Rio de Janeiro: Civilização Brasileira, s/d.

FALEIROS, V. de P. Saber Profissional e Poder Institucional. São Paulo: Cortez, 1987.

FARIA, José E. “Introdução: o Judiciário e o Desenvolvimento sócio-econômico”. In: Direitos humanos, direitos sociais e justiça. São Paulo: Malheiros, 1994: 11-29.

FÁVERO, E. T. (Org.) ; JORGE, M. R. T. (Org.) ; MELAO, M. J. R. (Org.) . O Serviço Social e a Psicologia no Judiciário - construindo saberes, conquistando direitos. $1^{\mathrm{a}}$. ed. São Paulo: Cortez, 2005. v. 01. 240 p.

O Serviço Social no sistema sócio-jurídico. In: CRESS 6 ${ }^{\mathbf{a}}$ Região

(org.). (Org.). Simpósio Mineiro de Assistentes Sociais - textos \& artigos. 1 ed. Belo Horizonte - MG: CRESS-MG, 2008, v. I, p. 31-38.

FOUCAUlT, M. "Teoria e Instituições Penais”. In: Resumo dos Cursos do Collège de France (1970 - 1982) / Michel Foucault; tradução, Andréa Daher; consultoria, Roberto Machado - Rio de Janeiro: Jorge Zahar Ed., 1997: 17-24.

"A sociedade punitiva". In: Resumo dos Cursos do Collège de France (1970 - 1982) / Michel Foucault; tradução, Andréa Daher; consultoria, Roberto Machado - Rio de Janeiro: Jorge Zahar Ed., 1997: 25-44.

- Vigiar e Punir: história da violência nas prisões, Petrópolis, Editora Vozes, 1996, 13ª edição, tradução de Raquel Ramalhete.

GIL, Antonio Carlos. Métodos e técnicas de pesquisa social. 3.ed. São Paulo: Atlas, 1991.

GOFFMAN, E.. Manicômios, prisões e conventos. São Paulo: Perspectiva, 1997.

GRANEMANN, Sara. Processos de Trabalho e Serviço Social 1. In: Capacitação em Serviço Social e Política Social. Módulo 2: Crise Contemporânea, Questão Social e Serviço Social. Brasília: CFESS/ABEPSS/ CEAD-UnB, 1999, pp. 153-166

GUILHEM, D. ; DINIZ, D. . O que é ética em pesquisa. 1. ed. São Paulo: Brasiliense, 2008. v. 1. 105 p. 
GOMES, E.S. e BARBOSA, E.F. 1999. A Técnica de Grupos Focais para Obtenção de Dados Qualitativos. Instituto de Pesquisa e Inovações Educacionais - Educativa. 30 de Agosto de 2000. Disponível em: 〈htttp://Www.educativa.org.brì

IAMAMOTO, M. "Questão social, família e juventude: desafios do trabalho do assistente social na área sociojurídica". In: SALES, M. Política social, família e juventude: uma questão de direitos. São Paulo: Cortez, 2004:261-295.

O Serviço Social na contemporaneidade: dimensões históricas, teóricas e ético-políticas. Fortaleza, CRESS -CE, Debate n. 6, 1997.

IBGE - FUNDAÇÃO INSTITUTO BRASILEIRO DE GEOGRAFIA E ESTATÍSTICA. Pesquisa mensal de empregos. Indicadores IBGE. Rio de Janeiro: IBGE, 2009. Disponível em: 〈http://Www.ibge.gov.br

Série Relatórios Metodológicos. Pesquisa Mensal de Emprego. $2^{\mathrm{a}}$ ed. Rio de Janeiro: IBGE, 2007, v. 23.

IPEA - INSTITUTO DE PESQUISA ECONÔMICA APLICADA. Panorama Conjuntural. Boletim de Conjuntura. Rio de Janeiro, n.78, Setembro 2007. Disponível em: 〈htttp://www.ipea.gov.br>1.

SILVA, J. F. S.. O recrudescimento da violência nos espaços urbanos: desafios para o Serviço Social. Serviço Social e Sociedade, v. 89, p. 130-154, 2007.

LAVINAS, Lena. Pobreza e Exclusão: traduções regionais de duas categorias da prática. In. Revista Econômica, v.4, n.1, junho 2002. (pp. 25-59).

LESSA, Sergio. Serviço Social, Trabalho e Reprodução. In: Revista Serviço Social e Movimento Social. v. 1, nº 2. São Luís: EDUFMA, jul./dez., 2000, pp. 07-29

LUKACS, G. História e Consciência de Classe. Publicações Escorpião, Porto, 1923.

MACHADO, L. M. Breve Estudo sobre a Reincidência Penal. LEX Editora, Publicado _ _ _ _ _ em _ _ _ _ _ 12/07/2006. _ _ _ _ Disponível _ _ _ em: 4http://www.lex.com.br/noticias/artigos/default.asp?artigo_id=958644\&dou=1

MARX, Karl e ENGELS, Friedrich. Manifesto do Partido Comunista. $4^{\circ}$ ed. SP, Global 1984.

MEDEIROS, Bernardo Abreu . Do Estado Social ao Estado Penal: a criminalização da miséria. In: XVI Congresso Nacional do Conselho Nacional de Pesquisa e PósGraduação em Direito no Brasil, 2007, Belo Horizonte. Anais do XVI Congresso Nacional do Conselho Nacional de Pesquisa e Pós-Graduação em Direito no Brasil CONPEDI, 2007. 
MIOTO, Regina Celia Tamaso . Família e Política Social. In: Boschetti, I; Behring, E. R.; Santos, S. M. M.; Mioto, R.C. T. (Org.). Política Social no Capitalismo: tendências contemporâneas. São Paulo: Cortez Editora, 2008, v. , pp. 130-148.

PAUGAM, S. A Abordagem Sociológica da Exclusão. In: Véras, M. P. Por uma Sociologia da Exclusão. O Debate com Serge Paugam. São Paulo: EDUC, 1999.

PEQUENO, A. Serviço Social e o campo sócio-jurídico. Palestra proferida no Encontro de Assistentes Sociais do Sistema sócio-jurídico Paranaense. Universidade Estadual de Londrina - UEL, 26 de junho de 2008.

PEREIRA, P. A. P. . Discussões Conceituais sôbre Política Social como Plítica Pública e Direito de Cidadania. In: BOSCHETTI, I.; BEHRING, E. R.; SANTOS, S. M. M.; MIOTO, R. C. T.. (Org.). Política Social no Capitalismo: tendências contemporâneas. São Paulo: Cortez, 2008. v. 1, p. 87-108.

A Política Social no contexto da seguridade social e do Welfare

State: a particularidade da assistência social. In: Serviço Social e Sociedade, n. 56. São Paulo: Cortez, 1998.

PIRES, M. F. C. Education and the historical and dialectical materialism. Interface — Comunicação, Saúde, Educação, v.1, n.1, 1997.

POCHMANN, M. ; ANTUNES, Ricardo Luiz Coltro . La desconstrucción del trabajo y la explosión del desempleo estructural y de la pobreza en Brasil. In: Alberto D. Cimadamore; Antonio David Cattani. (Org.). Producción de pobreza y desigualdad en América Latina. 1 ed. Bogotá: Siglo del Hombre Editores, 2008, v. 1, p. 191-204.

REGO, M. I. P. . Sociologia da Prisão. In: BANDEIRA, L.; COSTA, A.T.M.. (Org.). Violências e Conflitualidades. 1 ed. Brasília: universidade de Brasília, 2004, v. 19, p. 01-281.

RICHARDSON, Roberto J. "Métodos Quantitativos e Qualitativos". In: Pesquisa Social: Métodos e Técnicas. $3^{a}$ ed. São Paulo. Ed Atlas. 1999: 29-48.

SALLA, F. A. . Rebeliões nas Prisões Brasileiras. In: Serviço Social e Sociedade, São Paulo, v. 67, p. 18-37, 2001.

SETUBAL, A. A. Pesquisa em Serviço Social: utopia e realidade. 3 ed. São Paulo: Cortez, 2005.

SOUZA, M. F. de. Condições, Determinações e Particularidades do Processo de Trabalho do Assistente Social nos órgão do Poder Judiciário Sediados em Brasília. Brasília, 2004. Dissertação de Mestrado do Programa de Pós-Graduação em Política Social, Departamento de Serviço Social da Universidade de Brasília.

STEIN, R. H. . Configuração recente dos programas de transferência de renda na América Latina: focalização e condicionalidade. In: BOSCHETTI, I.; BEHRING, E. R.; 
SAntOS, S. M. M.; MIOTO, R. C. T.. (Org.). Política Social no Capitalismo: tendências contemporâneas. São Paulo: Cortez, 2008, v. , p. 196-219.

TEIXEIRA, Bruno Ferreira. Gato escaldado em teto de zinco quente: uma análise sobre os egressos do sistema penitenciário. Dissertação de mestrado, UFRJ/CFCH, Rio de Janeiro: 2007.

VAlENTE, M. L. C. da S. O Serviço Social e a Expansão do Judiciário: Uma Reflexão Introdutória. Libertas, Juiz de Fora, v.1, n.1, p.44 - 68, dez / 2006 ISSN1980-8518.

VALLADARES L. P. . Cem anos pensando a pobreza (urbana) no Brasil. In: BOSCHI R. R., organizador. Corporativismo e desigualdade: a construção do espaço público no Brasil. Rio de Janeiro: Rio Fundo Editora; 1991. p. 81-112.

WACQUANT, Loic. As prisões da miséria. Rio de Janeiro: Zanhar, 2001.

WIGHTMAN, Joana. 18 detentos e 33 menores não retornaram, após o Natal. Jornal de Brasília, Brasília, 30 de dezembro de 2008. Caderno Notícias Cidades.

ZANETTINI, P; MARQUES, M. DO LADO DE FORA. Rio de Janeiro: Log On Editora Multimidia, 2005. DVCAM (55 min.), col. Livre. 


\section{ANEXO I}

\section{GUIA DE ENTREVISTA}

\section{PROCESSOS DE TRABALHO DA ASSISTENTE SOCIAL}

Nome:

Tempo de atuação como assistente social:

Tempo de atuação como assistente social na Seção Psicossocial da VEP:

Tempo de atuação junto a sentenciados em regime Semi-Aberto ou Aberto:

1. Fale-me do surgimento da Seção Psicossocial da Vara de Execuções Penais VEP: movimentos que levaram a sua constituição - demandas dos usuários? Demanda do juiz da execução?

2. Fale-me do surgimento do Serviço Social na Seção Psicossocial da Vara de Execuções Penais - VEP: desde a constituição da Seção?

3. Fale-me dos processos de trabalhos da Assistente Social: do momento da chegada do processo a Seção até a sua remessa de volta ao cartório, relações de poder, interdisciplinaridade ou multidisciplinaridade?

4. Fale-me dos usuários do Serviço Social na Seção Psicossocial da VEP: demanda espontânea? demanda interna ou externa?

5. Como a Senhora analisa a sua intervenção junto aos sentenciados? Objetivos, alcance dos objetivos.

6. Como a Senhora avalia o seu trabalho? Qual a importância de ele ser executado para a sociedade?

7. Quais os desafios e dificuldades da atuação profissional? Projetos, intervenção conjunta entre os vários saberes.

8. A Senhora gostaria de falar mais alguma coisa?

9. A Senhora gostaria de ter os dados de pesquisa devolvidos? Se Sim, deixe e-mail ou endereço para posterior postagem. 


\begin{abstract}
ANEXO II
GUIA DE ENTREVISTA INDIVIDUAL E DE GRUPO FOCAL
\end{abstract}

1. Qual a percepção dos Senhores sobre a situação que levou o parente ou amigo de vocês a se tornar um sentenciado? Motivações sociais, comportamentais e culturais para a execução do crime.

2. De que forma a execução penal (re)socializa esse indivíduo? Entendimento do que é a Justiça como ela se media, percepção do sistema penitenciário - suas falhas e possibilidades.

3. O atendimento com a Assistente Social de alguma forma pode contribuir para a (re)socialização desses sentenciados? De que maneira os Senhores compreendem esse atendimento? Qual importância dele? Direcionamento do grupo para o questionamento desse trabalho realizado pela equipe, como os familiares o concebem: uma forma de emancipação do sujeito ou como apenas uma etapa em direção ao retorno do sentenciado?

4. Informar sobre os dados da DEPEN sobre reincidência penal e índice de foragidos no Distrito Federal bem como sobre a singularidade do trabalho realizado na SEVEP. A partir disso, suscitar o debate a cerca dessas informações: os participantes vêem alguma ligação entre a atuação da Assistente Social na SEVEP e os dados levantados?

5. Os Senhores têm mais algo mais a dizer?

6. Os Senhores gostariam de receber os dados da pesquisa? Se Sim, deixe e-mail ou endereço para posterior postagem. 


\section{ANEXO III}

\section{TERMO DE CONSENTIMENTO LIVRE ESCLARECIDO}

Este documento visa solicitar a sua participação na Pesquisa "As Percepções dos Usuários e Assistentes Sociais sobre o Trabalho do Serviço Social na Seção Psicossocial da Vara de Execuções Penais", que tem como objetivo analisar a contribuição do trabalho do Assistente Social para os reduzidos índices de foragidos e reincidentes no Distrito Federal. Esse estudo é realizado pela aluna-pesquisadora: Thaís Caroline Sena de Oliveira (contato: 8117-3047) e visa produção do Trabalho de Conclusão de Curso em Serviço Social na Universidade de Brasília.

Por intermédio da assinatura deste Termo são garantidos os seguintes direitos aos seus signatários: (1) solicitar, a qualquer tempo, maiores esclarecimentos sobre esta Pesquisa; (2) sigilo absoluto sobre nomes, apelidos, datas de nascimento, local de trabalho, bem como quaisquer outras informações que possam levar à identificação pessoal; (3) ampla possibilidade de negar-se a responder a quaisquer questões ou a fornecer informações que julguem prejudiciais à sua integridade física, moral e social; (4) opção de solicitar que determinadas falas e/ou declarações não sejam incluídas em nenhum documento oficial, o que será prontamente atendido; (5) desistir, a qualquer tempo, de participar da Pesquisa.

"Declaro estar ciente das informações constantes neste 'Termo de Consentimento Livre e

Esclarecido e compreender que uma cópia deste documento ficará guardado com a alunapesquisadora”.

Brasília, de de 2009

Participante:

Telefone:

Endereço: 
Thaís Caroline Sena de Oliveira\} 
This document was created with Win2PDF available at http://www.win2pdf.com.

The unregistered version of Win2PDF is for evaluation or non-commercial use only.

This page will not be added after purchasing Win2PDF. 